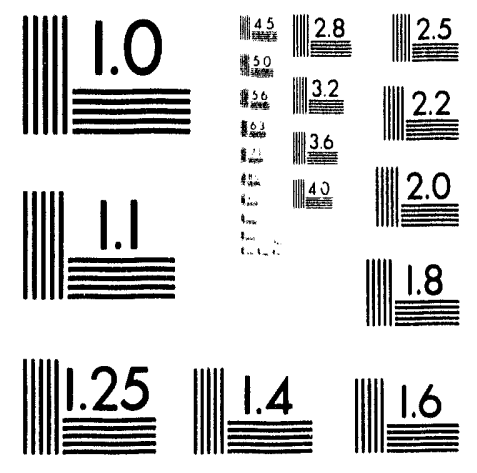



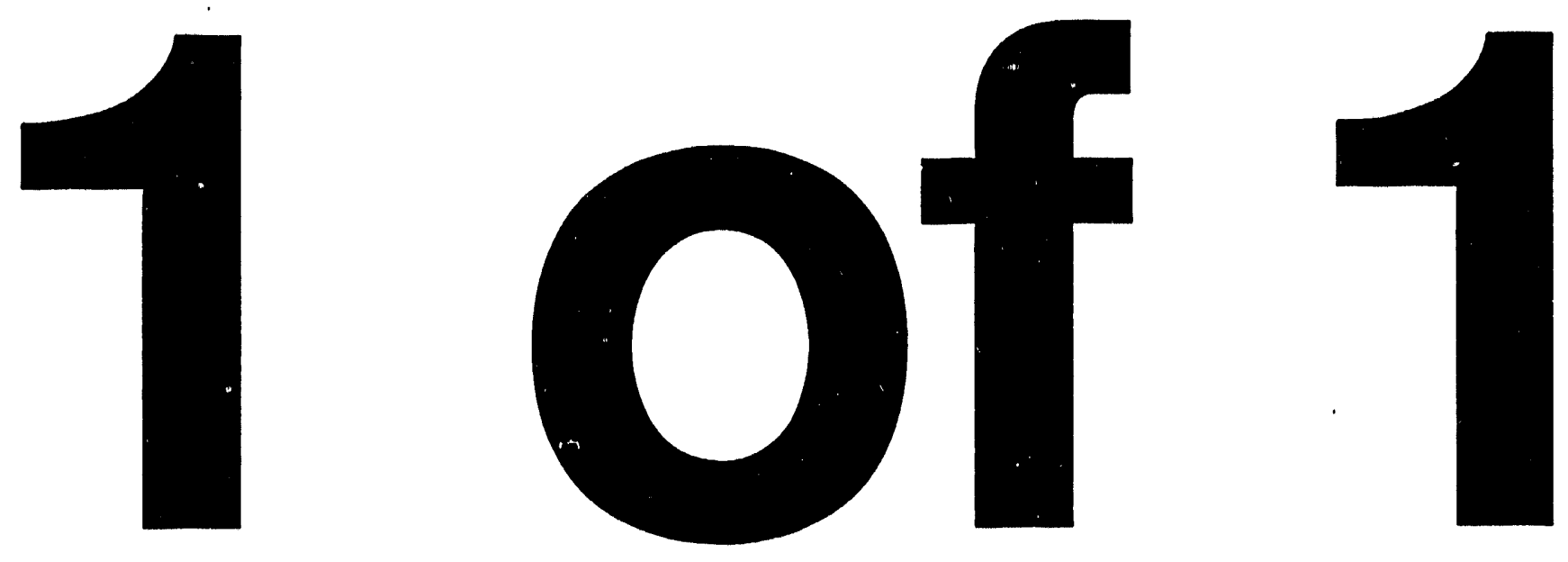


\title{
Results of Examinations of Pressure Vessel Samples and Instrument Nozzles from the TMI-2 Lower Head
}

by

\author{
G. E. Korth \\ Idaho National Engineering Laboratory \\ EG\&G Idaho, Inc. \\ Idaho Falls, ID 83415
}

and

D. R. Diercks and L. A. Neimark

Energy Techn Jlogy Division

Argonne Nation al Laboratory

Argonne, IL 60439

October 1993

\section{DISCLAIMER}

\begin{abstract}
This report was prepared as an account of work sponsored by an agency of the United States Government. Neither the United States Government nor any agency thureof, nor any of their employees, makes any warranty, express or implied, or assumes any legal liability or responsibility for the accuracy, completeness, or usefulness of any information, apparatus, product, or process disclosed, or represents that its use would not infringe privately owned rights. Reference herein to any specific commercial product, process, or service by trade name, trademark, manufacturer, or otherwise does not necessarily constitute or imply its endorsement, recommendation, or favoring by the United States Government or any agency thereof. The views and opinions of authors expressed herein do not necessarily state or reflect those of the United States Government or any agency thereof.
\end{abstract}

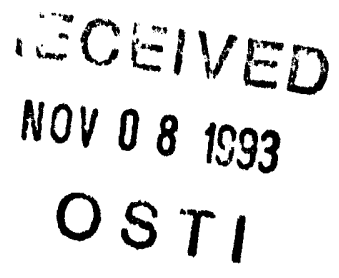

To be presented at the 21 st Water Reactor Safety Meeting, Rockville, MD, October 25-27, 1993.

*Work supported by the Office of Nuclear Regulatory Research, U. S. Nuclear Regulatory Commission and by the Organisation for Economic Cooperation and Development. 


\title{
Results of Examinations of Pressure Vessel Samples and Instrument Tube Nozzles from the TMI-2 Lower Head
}

\author{
G. E. Korth \\ Idaho National Engineering Laboratory \\ D. R. Diercks and L. A. Nelmark \\ Argonne National Laboratory
}

\begin{abstract}
Fifteen prism-shaped steel samples were removed from the lower head of the damaged TMI-2 reactor pressure vessel to assess the effects of approxdmately 19 metric tons of molten core debris that had relocated there during the 1979 loss-of-coslant accident. Metallograph'c examinations of the samples revealed that inside surface temperatures of 800 to $1100^{\circ} \mathrm{C}$ were attained during the accident in an elliptical shaped "hot spot" $\approx 1 \times 0.7 \mathrm{~m}$. Tensile, creep, and Charpy V-notch specimens were also cut from the samples to assess the mechanical properties of the lower head material at temperatures up to the peak accident temperature. These properties were used in a margin to fallure analysis of the lower head. Examinations of instrument nozzles removed from the lower head region assisted in defining the relocation scenario of the molten core debris and showed thai the lower head was largely protected from catastrophic fallure by a solidified layer around the molten core dubris that acted as a paitial thermal insulator.
\end{abstract}


The TMI-2 I c.isel Investigation Project (VIP) is an international program conducted jointly by the U.S. Nuclear Regulatory Commission (NRC) and the Organisation for Economic Co-operation and Development/Nuclear Energy Agency (OECD/NEA). The objectives of the program are to (1) determine a scenario for the Three Mile Island Unit 2 Nuclear Reactor loss-of-coolant accident in March 1979 and deduce the thermal history of the steel in the lower vessel head during the accident, (2) determine the mechanical propertles of the lower head steel under the accident conditions, and (3) assess the Integrity of the TMI-2 lower head under the accident conditions. Particlpants in the project include the U.S., Japan, Belgium. the Federal Republic of Germany (FRG), FInland, France, Italy, Spain, Sweden, Switzerland, and the United KIngdom (U.K.). $1-12$

The relocation of $\approx 19,000 \mathrm{~kg}$ of molten core debris onto the lower head of the reactor pressure vessel during the accident caused a considerable threat to the integrity of the pressure vessel. The lower head is comprised of 136 -mm-thick A533B pressure-vessel steel with a 5-mm Type 308L stainless steel clad, and this quantity of molten debris had the potenthal of melting the lower head or causing $1 t$ to fall by short-term creep under the tensile loadings present during the accident. The fact that the lower head did not fall indicates that significant melting did not occur and that time at temperature was not sumcient to produce creep fallure under the loadings prescnt. The purpose of the present investigation was to assess the extent of damage present in the lower head region, determine the maximum temperature of that material during the accident, and measure the mechanical properties of that material under the accident conditions.

Fifteen prism-shaped samples, each $\approx 152-178 \mathrm{~mm}(6-7 \mathrm{in.})$ long. $64-89 \mathrm{~mm}(2.5-3.5 \mathrm{in}$. wide, and 64-76 $\mathrm{mm}$ (2-1/2-3 in.) deep, were recovered from the TMI-2 lower head during the first phase of the program (Fig. 1). The samples were cut from the inner surface of the lower head and typically extend through approximately half the lower head thickness. These 15 samples were subjected to detalled intial examinations and were then sectioned into metallographic and mechanical test specimens for further characterization (Fig. 2). The results of the initial sample examinations, metallographic studies, and mechanical tests are reported here.

In addition, 14 instrument nozzles and two guide tubes were removed from the lower head, and examinations of these components provided additional information on the core debris relocation scenario and the maximum temperatures attained during the accident. The results of these examinations are also reported here.

\section{Initial Examination of Lower Head Samples}

The 15 samples were received at Argonne National Laboratory (ANL) for visual examination, photography, dimensional measurement, and decontamination, to allow the subsequent machining operations to be relatlvely free of contamination.

The cladding surface of most samples was covered with a loose debris. Later analyses of scrapings of these surfaces indicated the material was principally an Fe-oxide with particulates of various core materials. A number of samples contalned depressions of various shapes in the cladding, some of which appeared to be surrounded by locally melted cladding. 


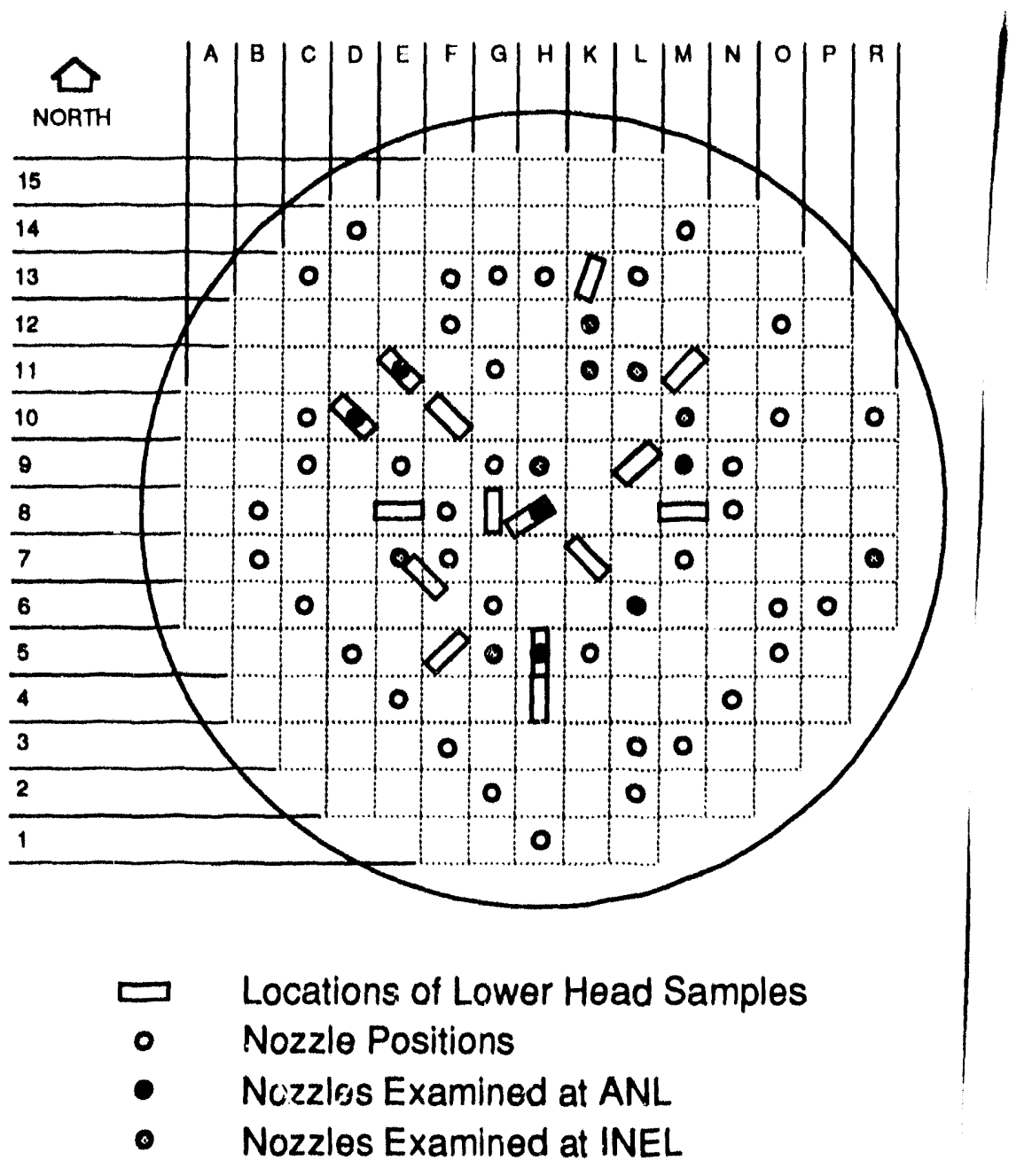

Fig. 1. Grid map of TMI core showing locations of lower head samples and nozzles.

Apparently these depressions were the result of false starts in the metal disintegration machining (MDM) method for removing the samples from the vessel. Also, the cladding at the end of the H-8 sample appeared to have separated from the vessel substrate. This was later attributed to the need to use mechanical force to pry this sample from the vessel.

The cladding on Sample E-6 was known to be cracked before its arrival at ANL. Cladding cracks were also seen at location G-6 in the lower head, but no sample was removed at this location. The visual inspection at ANL. found the G-8 sample also be cracked, in a manner similar to that of E-6. Photographs of the cracks in E-6 and G-8 are shown in Fig. 3. These two samples were subsequently sectioned for metallographlc and SEM-EDX analyses. Because of its cracks and the desire not to disturb the material within the cracks, sample G-8 was not chemically decontaminated as were the other samples. Its examination was done remotely in a hot-cell because of its high activity, whereas the other samples could be handled outside of a hot-cell after decontamination. 


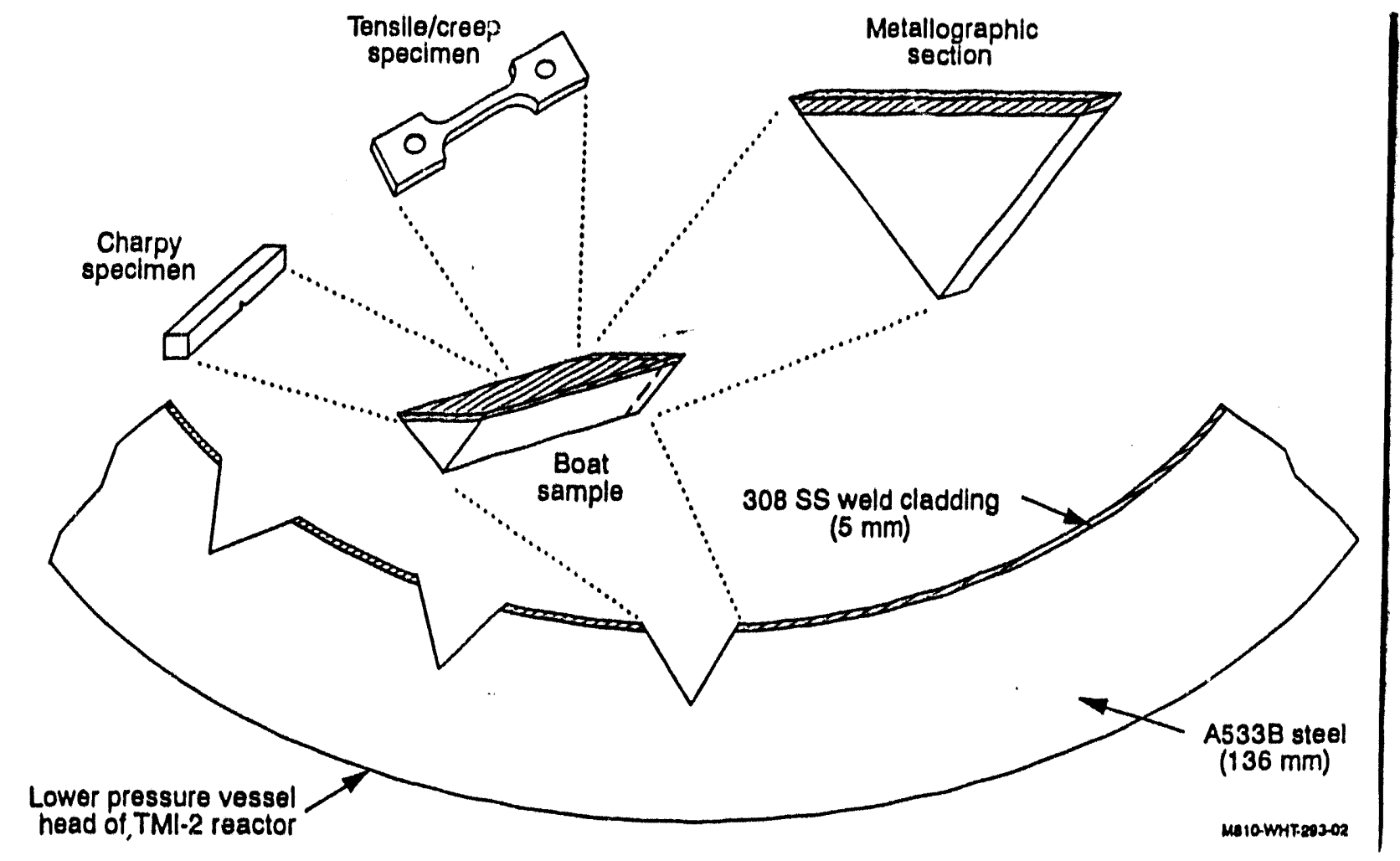

Fig. 2. Schematic of the source of the TMI-2 metallographic and mechanical property samples.

Sample decontamination was accomplished in a static bath of $50 \%$ solution of $\mathrm{HCl}$ in water for perjods ranging from $50 \mathrm{~min}$. to $5 \mathrm{hrs}$. For three samples it was necessary to use an additional 2-3 min. dip in concentrated nitric acid in order to get the samples down to acceptable activity levels. After these decontamination steps, it was possible to see the features of the original cladding weld passes on a number of samples. It was noted at that time that the cladding surface of sample F-10 contained micro-cracking at the grain boundaries in some of the weld passes. Because these micro-cracks have different morphology than the larger cracks in E-6 and G-8, they may or may not have resulted from the accident. The F-10 area, however, is on the edge of the hot-spot location found in the vessel.

\section{Detalled Metallographic Studies}

Following the initial examinations, metallographic specimens were cut from the lower head samples, decontaminated, and sent to the Idaho National Engineering Laboratory (INEL). These specimens were subjected to detalled characterization by optical metallography and hardness measurements to determine the maximum temperature attained at various lower head locations during the accident Supplemental examinations were also conducted by ANL and participating OECD partner laboratories. 


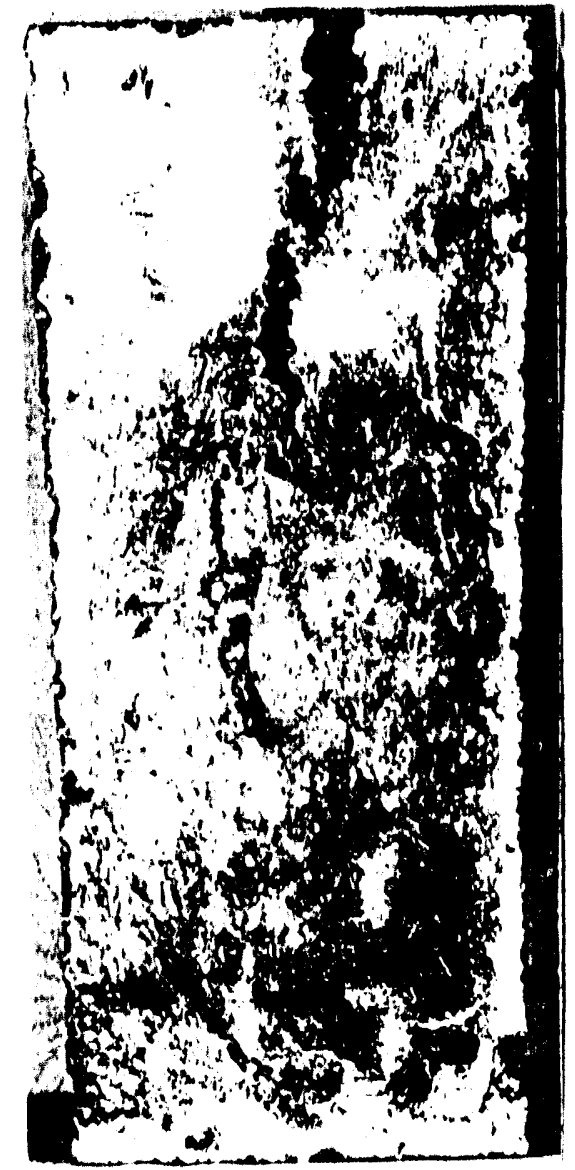

Sample E-6

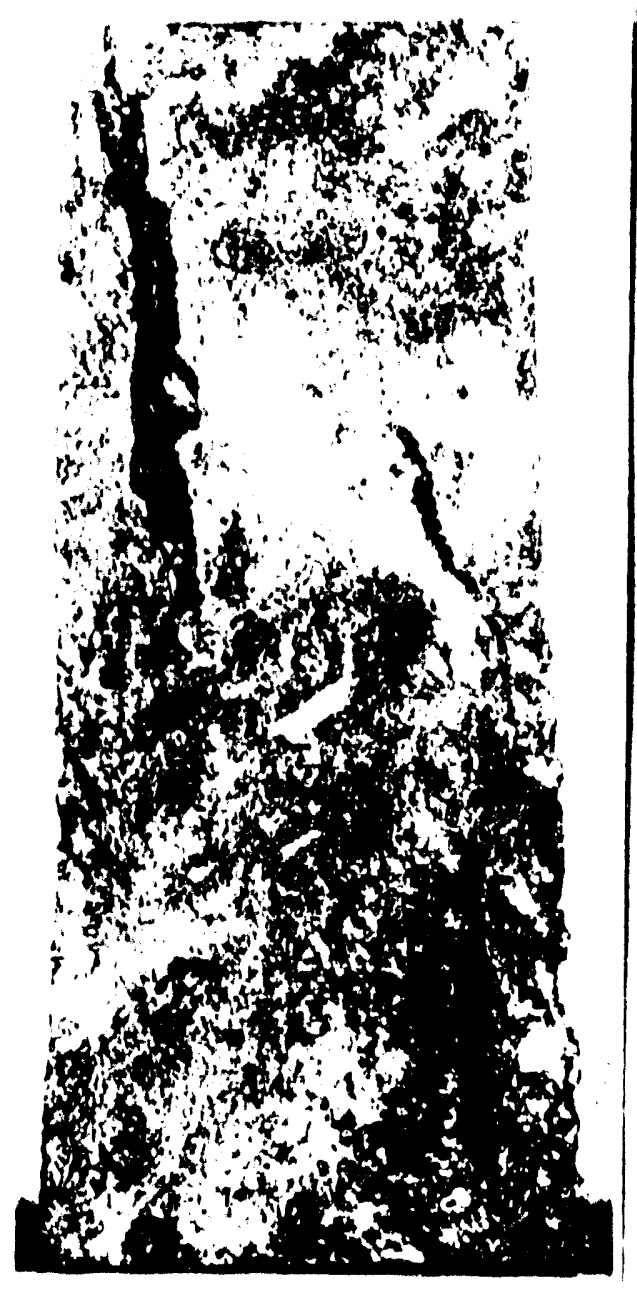

Sample $6-8$

Fig. 3. Top views of Samples E 6 and $G 8$ showing cracking in the vessel cladding.

Background Information. The TMI-2 pressure-vessel lower head was fabricated from A533. Grade B low-alloy ferritic steel and clad for corrosion protection with Type 308L austenitic stainless steel using a mult tple-wire submerged arc welding process. The labrication history of the vessel is summarized as follows: $137 \mathrm{~mm}$ (minimum) plate formed to shape by hut pressing, austenttked at $871-899^{\circ} \mathrm{C}$ for $5.5 \mathrm{~h}$, brine quenched anci tempered at $649^{\circ} \mathrm{C}$ for $5.5 \mathrm{~h}$, clad on the Insicte with $4.8 \mathrm{~mm}$ (minimum) ER308L, stalnless steel, and then stress relleyed at $607^{\circ} \mathrm{C}$ lor $50 \mathrm{~h}$.

Since the amount of materlal extracted from the TMI-2 vessel was limited, archlve A533B steel was also obtained from the abandoned Midland reactor, whlch had never been put into service. The Midland reactor pressure vessel was of the same vintage as the TMI- 2 vessel. was bullt by the same contıactor, and had a very simllar fabrication history. The Midland 
material was plentiful and provided a valuable resource for studying propertles and accidentsimulated thermal response of lower head matertal.

The weld cladding overlay and the fabrication history as described above left their "thermal signature" on the lower head. This as-fabricated condition was further thermally altered in some cases by the molten core debris that relocated during the accident. The typical as-fabricated condition (microstructure and hardness) as found in the TMI-2 and Midland lower head material is illustrated in Fig. 4. A heat-affected zone (HAZ) of 7 to $12 \mathrm{~mm}$ is observed in the A533B steel directly adjacent to the stainless steel weld clad. The first 2 to $3 \mathrm{~mm}$ of the HAZ is made up of enlarged, partlally decarburtzed grains, and the remainder of this HAZ band is comprised of relined grains that reached temperatures above the ferriteaustenite transformation temperature of $727^{\circ} \mathrm{C}$ from the welding operation and were then quenched due to the massive heat sink provided by the remaining materlal thickness. Beyond the HAZ band, tempered bainite is observed uniformly throughout the remaining thickness. Any further thermal exposure equal to or greater than $727^{\circ} \mathrm{C}$ altered this as-fabricated structure and created a new thermal signature, which was used to determine the thermal history caused by the accident.

Three different methods of examination were used by the participating laboratories to assess the thermal history of the samples: (a) hardness proflles, (b) microstructure, and (3) thermally induced metallurgical modincations of the weld clad interface. The interfacial modilications were mainly a result of carbon diffusion from the A533B steel $(\approx 0.25 \% \mathrm{C})$ into the $308 \mathrm{~L}$ stainless steel clad $(0.035 \% \mathrm{C}$ max.). Typical hardness proflles were taken of the samples from the weld cladding to the bottom tip of the triangular piece. The microstructure was examined using standard optical metallographic practices. Electron microscopy (both scanning and transmission) were used by some laboratories in their examinations.

Hardness Measurements. The hardness profles of most of the TMI-2 samples had the typical characteristic proflle of as-fabricated material as shown in Fig. 4, but the hardness proflles from Samples E-6, E-8, F-10, and G-8 were markedly different than all other samples, as shown in Fig. 5. The characteristic hardness proflle through the HAZ band had risen sharply in these four samples to much higher levels and was then sustained throughout the full sample depth. Heat-affected bands from the weld cladding were not evident in these four samples, but were completely eliminated by the thermal effects of the accident.

Two other samples (H-8 and F-5) also showed anomalles in the hardness prolles. Hardness measurements of $\mathrm{H}-8$ in a longitudinal direction (parallel to the inside surface of the lower head) on several strips remaining after the tensile specimens were cut showed a hardness increase as the end closest to G-8 was approached. This observation indicates that the ferrite-austenlte transformation temperature was reached on the end of $\mathrm{H}-8$ nearest to G-8. The hardness protlle of F-5, as measured by some of the participating laboratories. showed some deviation from the typlcal weld cladding HAZ ellects, which indicates that temperatures in the vicinity of this sample slightly exceeded the $727^{\circ} \mathrm{C}$ threshold.

The Anal hardness of the TMI-2 samples is not only a strong indicator that the A533B steel transformation temperature of $727^{\circ} \mathrm{C}$ was exceded during the accident, but also allows some bounds on the cooling rate back through the phase change. To achleve the same hardness values on standards as observed in Samples E-6, E-8, F-10, and G-8, the cooling rate had to be in the range of 10 to $100^{\circ} \mathrm{C} / \mathrm{min}$. Studies with the Midland material showed that if the cooling rate had been in the vicinity of $1^{\circ} \mathrm{C} / \mathrm{min}$ or less, then the final hardness would have 

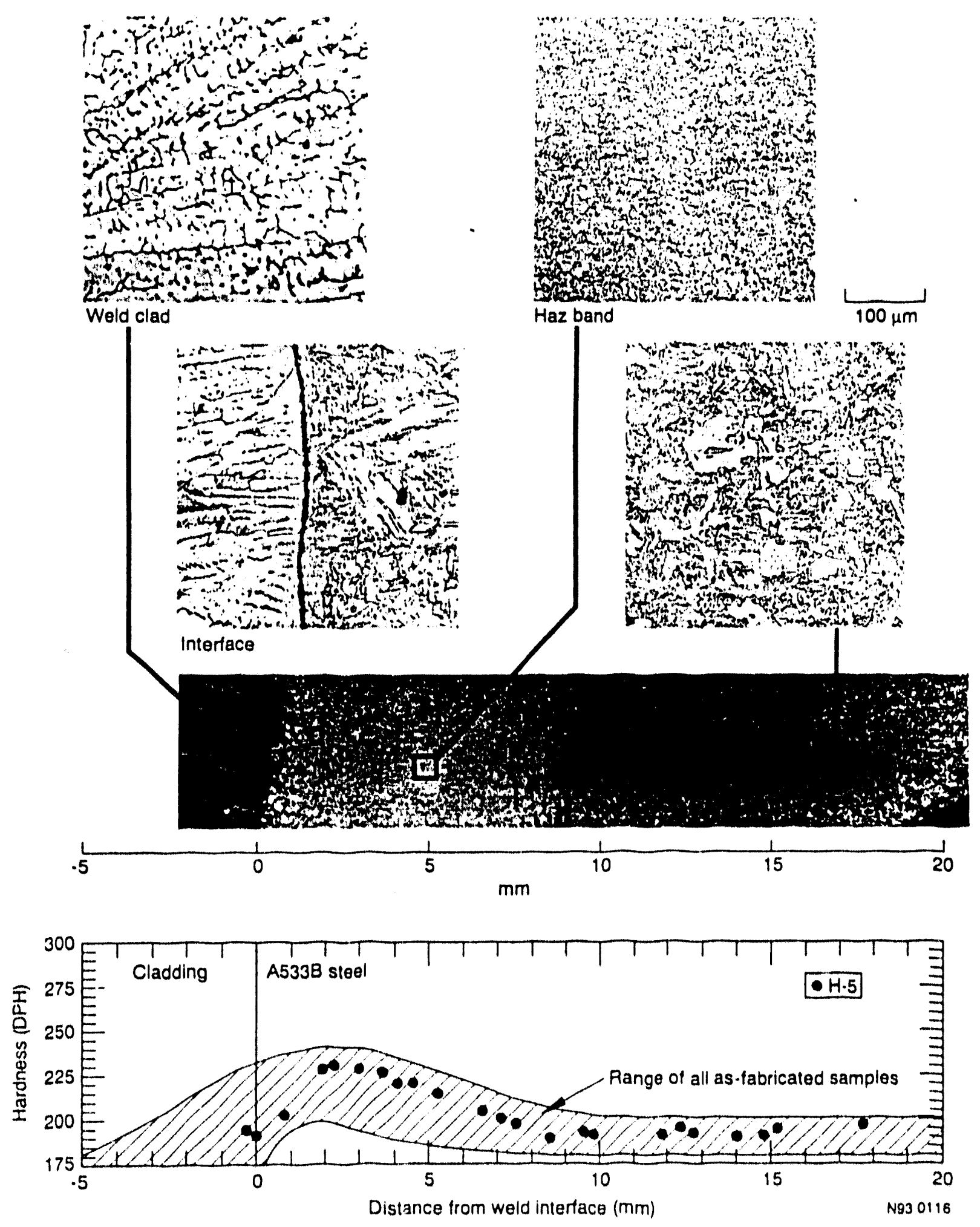

Fig. 4. Typical as fabricated microstructure and hardness of TMI 2 lower head material (from Sample: $(15)$. 


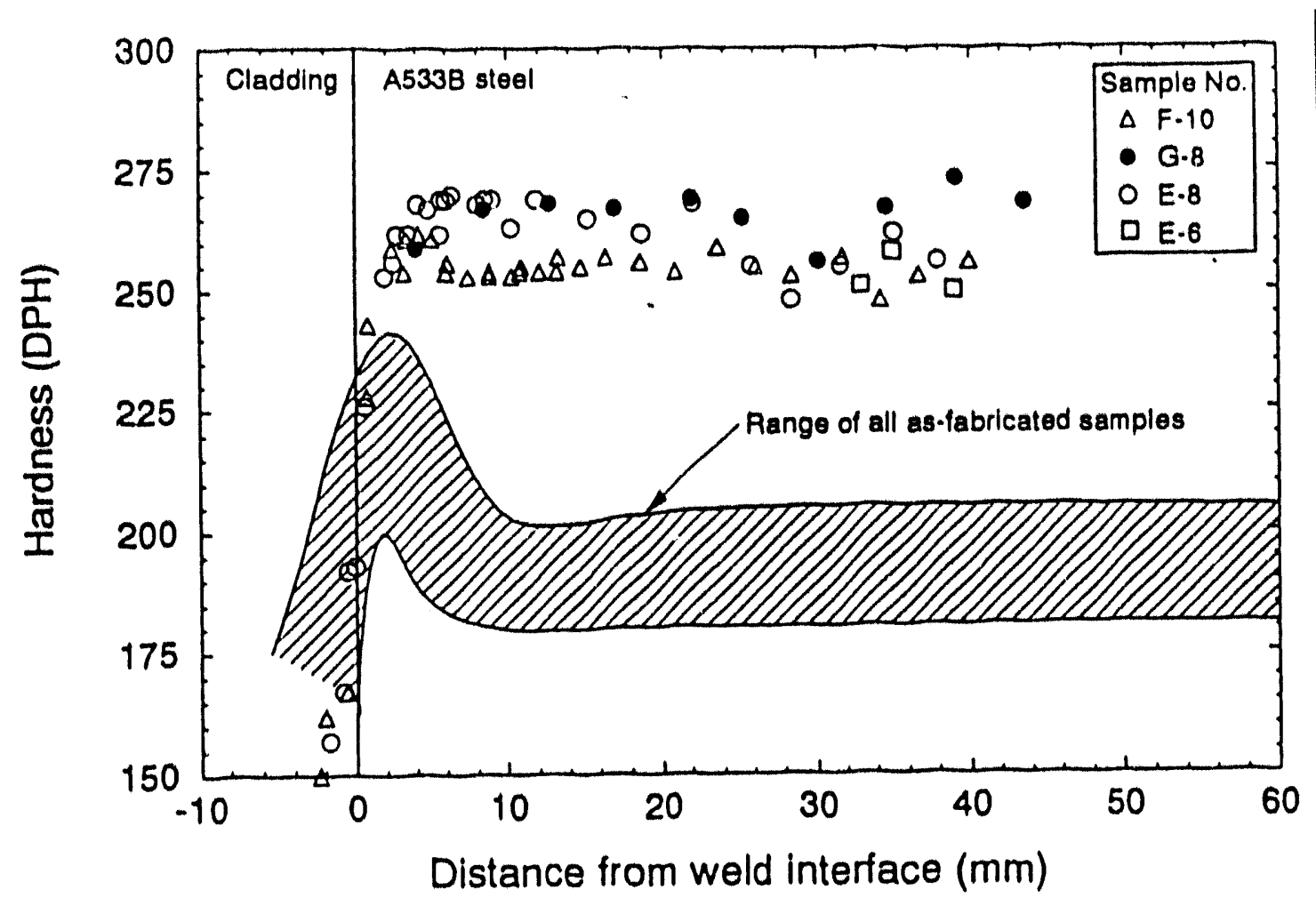

Fig. 5. Hardness profiles of Samples F-10, G-8, E-8 and E-6 compared to the as-fabricated samples.

been approximately the same as that of the as-fabricated parent metal. If that had been the case, hardness measurements would not have been very helpful in determining the thermal history due to the accident-they would only reveal that the hardness peak from the HAZ band from the weld cladding was ellminated. However, the final hardness values for E-8, F-10, G-8, and $\mathrm{E}-6$ are consistent with cooling rates $\geq 10^{\circ} \mathrm{C} / \mathrm{min}$ and any peak temperature above $800^{\circ} \mathrm{C}$. Therefore, hardness values of the TMI-2 samples are indicative of two things: (a) whether or not the material had exceeded the transformation temperature, and (b) if it had, some bounds on the cooling rate. Hardness values are not very concluslve as to the peak temperatures that may have been reached even though some trends were observed by ANL and France. From just the hardness measurements, It was concluded that F-5 and one end of $\mathrm{H}-8$ slightly exceeded $727^{\circ} \mathrm{C}$ and E-6, E-8, F-10, and G-8 exceeded $830^{\circ} \mathrm{C}$. Examination of the microstructure was used to assess peak temperatures after the inltial screening was performed with hardness measurements.

Midland Archive Standards. Standards with known thermal historles were prepared from Midland archive material and later from actual as-fabricated TMI-2 material. These accident-simulated standards provided a means for comparing a similar materlal with a known thermal history to TMI-2 material with an unknown thermal history. Initlally, standards were prepared to determine the effect of cooling rate through the austenite-ferrite transition temperature range, which aflects the hardness. Then, several laboratortes prepared standards from Midland archive material with maximum temperatures that ranged from 700 to $1300^{\circ} \mathrm{C}$ 
and with dwell times at peak temperatures of one minute to two hours. The heatup rate was controlled at $40^{\circ} \mathrm{C} / \mathrm{min}$, and the cooling rate following the dwell perlod was 1 to $100^{\circ} \mathrm{C} / \mathrm{min}$. Finally, as unknown thermal historles were narrowed down, an additional set of standards was prepared from some actual TMI-2 lower head materlal determined to be in the as-fabricated condition. These small sections of TMI-2 material were heat-treated at 950,1000,1050, and $1100^{\circ} \mathrm{C}$ for dwell times of 10,30 , and 100 minutes and provided the final basis for comparison to determine the thermal history of the lower head due to the accident.

As the standards were prepared and examined, various metallurgical observations revealed a step-wise process that could be used in determining the thermal historles of the TMI-2 samples. A diagram (shown In Fig. 6) was constructed, which lllustrates the metallurgical changes with time and temperature of the Midland and TMI-2 lower head A533B steel with a $308 \mathrm{~L}$ stainless weld clad. Since the vessel was stress relieved at $607^{\circ} \mathrm{C}$ after the weld cladding. no thermal effects from the accident could be detected at or below this temperature and, therefore, the diagram shows only metallurgical observations for temperatures above this point. The lowest temperature indicator, above the stress rellef temperature, was the ferrite-austenite transformation, which starts at $727^{\circ} \mathrm{C}$ and is complete by $=830^{\circ} \mathrm{C}$. Variations in the typical as-fabricated hardness profle will be evident when this threshold is exceeded. The next indicator is the dissolution or dissipation of a dark feathery band at the interface; this occurs between 800 and $925^{\circ} \mathrm{C}$. depending on the time. The next indicator of increasing temperature is the appearance of small equiaxed grains, which formed In the A533B steel adjacent to the interface at temperatures between 850 and $900^{\circ} \mathrm{C}$ and disappeared between 1025 and $1100^{\circ} \mathrm{C}$ as they were consumed by grain growth in the low alloy steel. The equiaxed grains, which are not typical for a low alloy steel, appear to be devold of cementite. probably due to a loss of carbon into the stainless steel. Grain growth in the A533B steel becomes significant above approximately 950 to $1075^{\circ} \mathrm{C}$, depending on the time involved. The highest temperature indicator shown on the diagram is the change in morphology of the $\delta$-ferrite islands in the stainless steel cladding. In the approximate range of 975 to $1000^{\circ} \mathrm{C}$ at 100 minutes or 1100 to $1125^{\circ} \mathrm{C}$ at 10 minutes, the $\delta$-ferrite islands begin to lose their slender branch-like morphology and become spherical in shape. This spheroldizing of the $\delta$-ferrite islands is belleved to be associated with the dissolution of $\mathrm{M}_{23} \mathrm{C}_{6}$ carbides, which decorate the ferrite-austenite boundaries and stabilize their shape. When the carbides dissolve, the $\delta$-ferrite becomes more spherical to minimize surface energy. There was also evidence that some of the $\delta$-ferrite was consumed into the austenitic matrix after exposures above $1000^{\circ} \mathrm{C}$ since there was a net loss of $\delta$-ferrite after cooling. Researchers in the Federal Kepublic of Germany ${ }^{7}$ and Spain $^{9}$ observed that $\delta$-ferrite in the cladding of nonaflected samples was $4-5 \%$, but only $1.4 \%$ in $\mathrm{E}-8$.

Microstructure of TMI-2 Samples. To further assess the thermal history of the four samples clearly showing thermal effects above the ferrite-austenite transformation temperature, microstructural indicators lllustrated in Fig. 6 were employed. Examinations of the microstructure of E-6, E-8, F-10, and G-8 showed that the dark feathery band had dissipated at the A533B steel/weld cladding interlace in all four samples. Ausionitic grain growth was evident in all four samples, with E-6 and E-8 showing the most pronounced effect. F-10 revealed that a small remnant of the cementlte-devold equlaxed small ferrite grains were still present, but none was evident in the other three. Spheroldization of the $\delta$-ferrite islands in the weld cladding was not readlly detected in $\mathrm{F}-10$, was partially observed in $\mathrm{G}-8$, and was fairly signincant in E-6 and E-8. By applying the above microstructural observations and meticulous comparisons with the standards of known thermal history, the lead laboratory for 


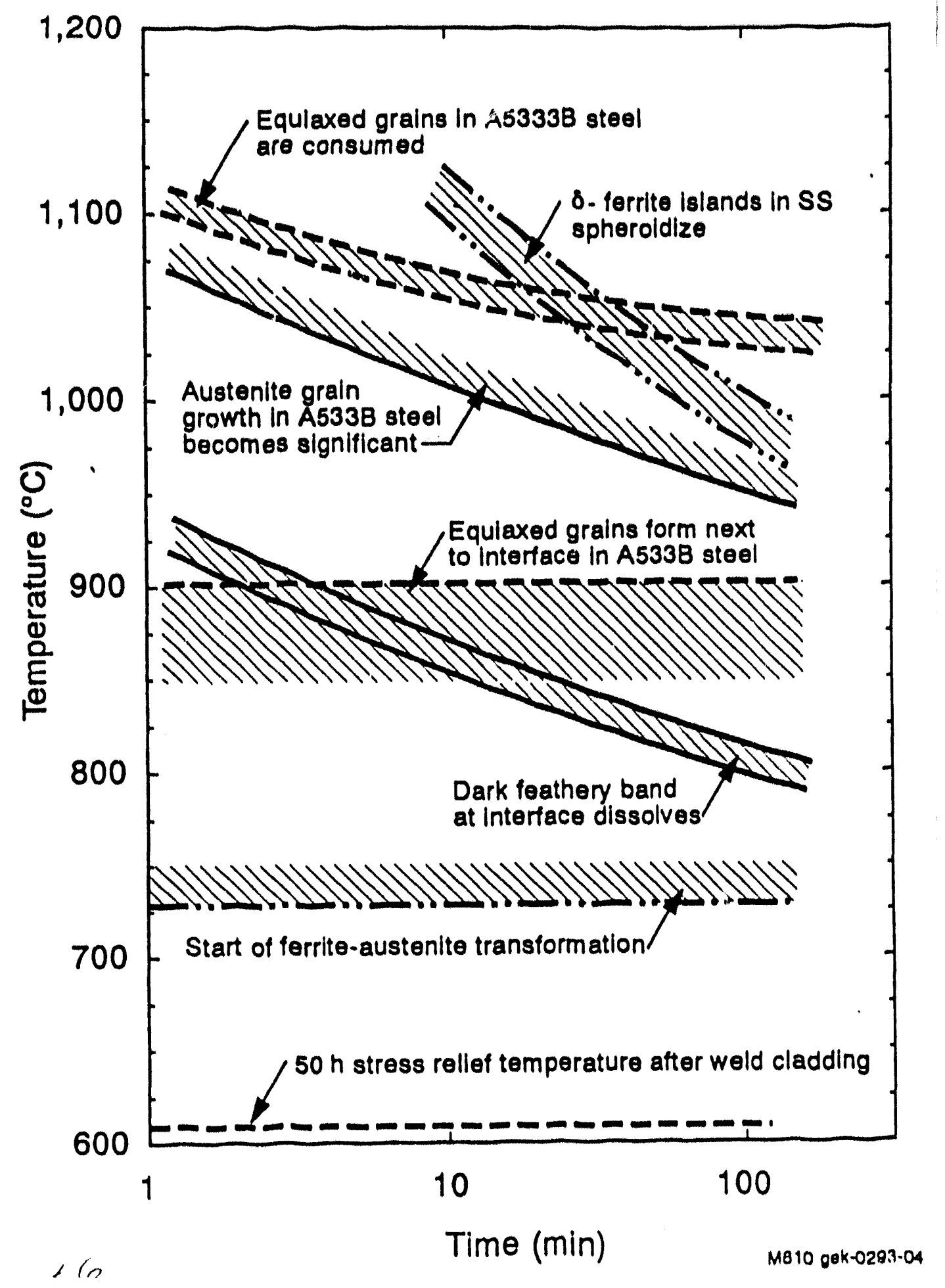

Fig. 6. Diagram of time-temperature observations of A533, Gr. B pressure vessel steel clad with Type 308L stainless steel. 


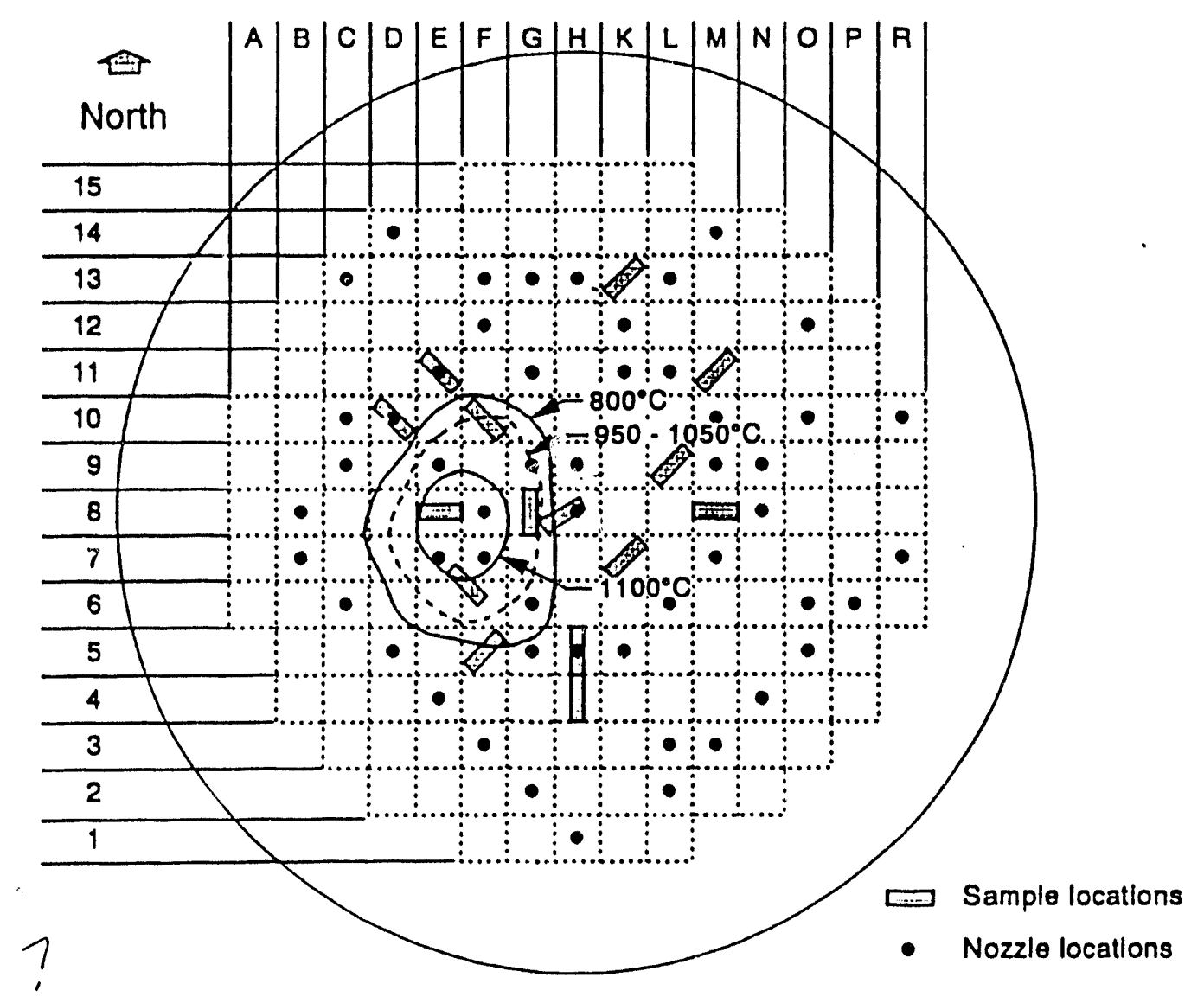

Fig. 7. Thermal contour map of peak temperature constructed as best estimate based on results of the metallographic examinations of the boat samples.

metallurgical examinations (INEL) estimated peak temperatures and time at temperature within $\approx 2.5 \mathrm{~mm}$ of the weld clad/base metal interface as follows:

- E-6 and E-8: $1075-1100^{\circ} \mathrm{C}$ for about 30 minutes

- F-10 and G-8: $1040-1060^{\circ} \mathrm{C}$ for about 30 minutes.

Examinations at ANL and some of the OECD partner laboratories for different sections of these same boat samples are consistent with the INEL conclusions. United Kingdom researchers showed evidence that $M-11$ also slightly exceeded the $727^{\circ} \mathrm{C}$ transformation temperature, but that determination was not confirmed by the other five laboratories examining different sections of the M-11 boat sample. Based on the above observations and conclusions, a thermal contour map of peak temperatures was constructed as shown in Fig. 7 . The hardness profle and microstructure of one of the thermally altered samples, E- 8 , is shown in Fig. 8.

The temperature gradient through the thickness of the lower vessel head wall $u$ as estimated by two methods. First, since the high level of hardness of the four affected samples persisted to the full depth of the boat samples $(50 \mathrm{~mm}$ from the inside surface or $45 \mathrm{~mm}$ 


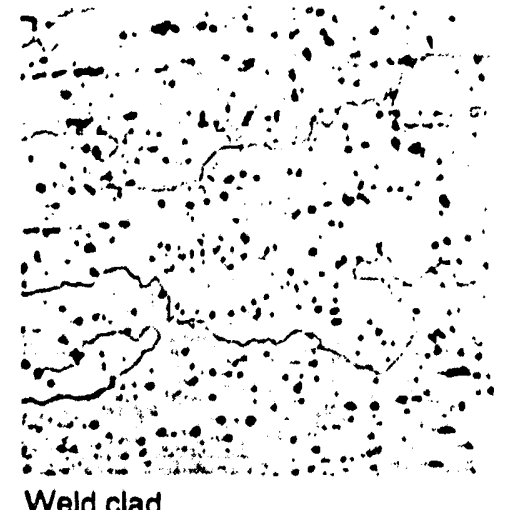

Weld clad
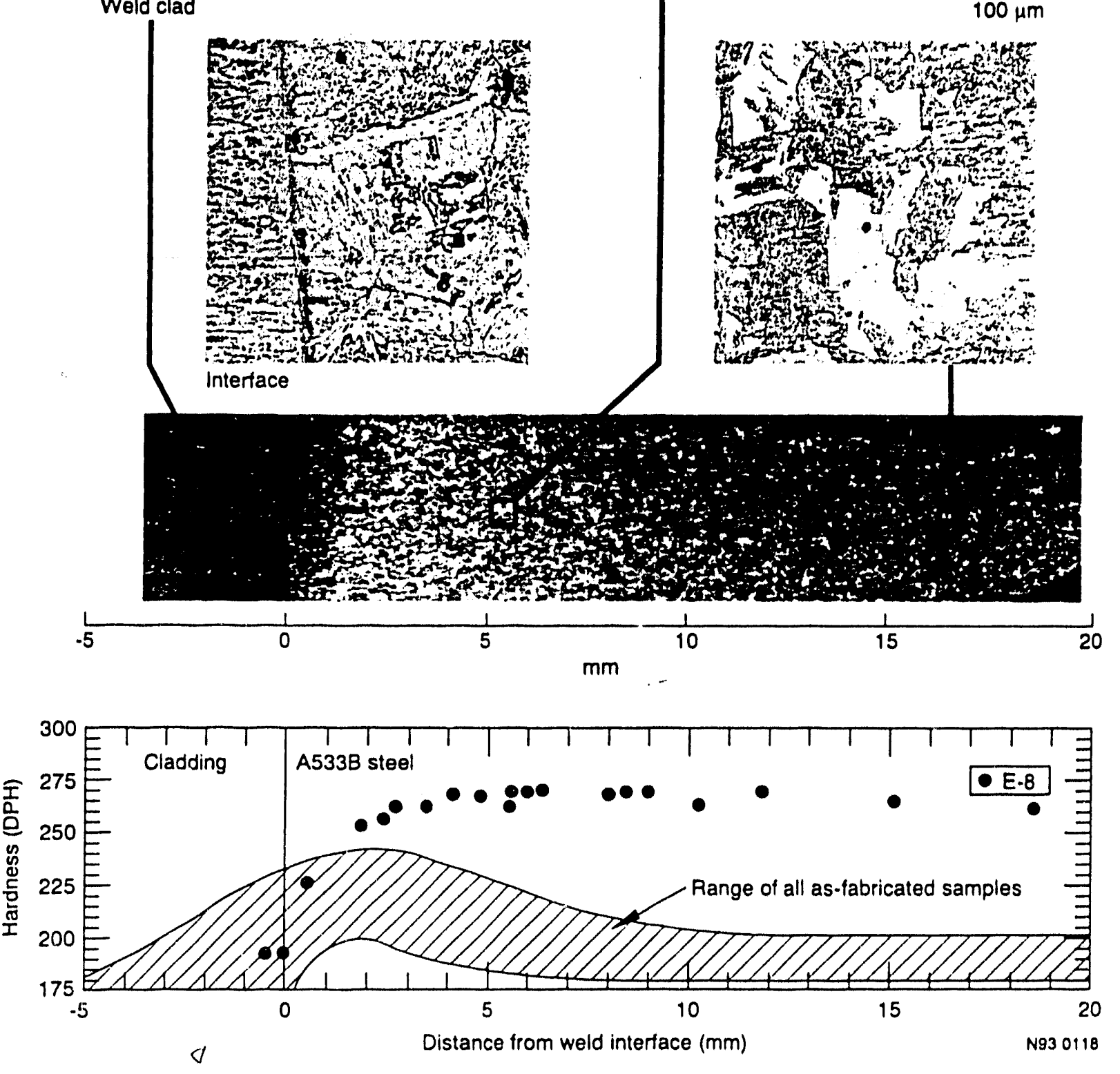

Fig. 8. Microstructure and hardness profile of Sample E-8. 


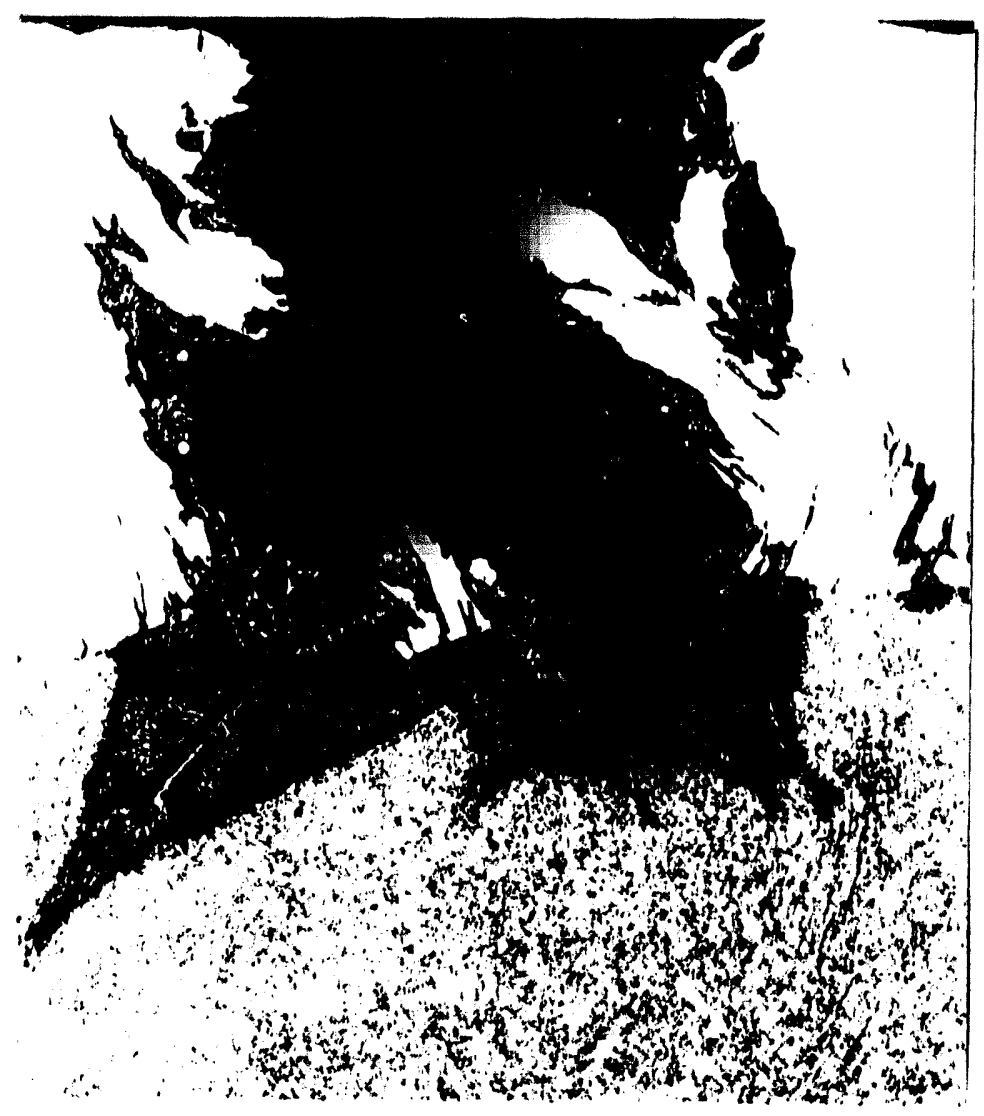

Fig. 9. Cross section through principal crack in Sample E-6.

from the weld clad interface; see Fig. 5), It could be concluded that the temperature at that depth was greater than the $727^{\circ} \mathrm{C}$ transformation temperature. Secondly, based on the assumption from the microstructure comparisons that the thermal excursion on the lower head due to the accident was on the order of 30 minutes, prior austenite grain size at the bottom-most tip of the heat-affected samples was compared with the prepared standards given the 30-minute heat treatments. The results of this comparison indicated that the temperature $50 \mathrm{~mm}$ from the inside surface $145 \mathrm{~mm}$ from the stainless steel/low alloy steel interface) was approximately $50-150^{\circ} \mathrm{C}$ lower than the peak temperatures determined previously for the region near the interface. By combining all the temperature gradtent estimates from INEL, ANL, and Finland, and assuming a linear relationship, the gradient appeared to be $2-4^{\circ} \mathrm{C} / \mathrm{mm}$.

Examination of Cladding Cracks. Results of the metallographic examinations through the cracks in samples $\mathrm{E}-6$ and $\mathrm{G}-8$ indicated that the cracking originated in and was essentlally limited to the Type 308L stainless steel cladding used on the vessel. A cross section through the principal crack in E-6 is shown in Fig. 9. Penetration into the A533 vessel steel was only superficial $(\approx 3 \mathrm{~mm})$. This was also the case for the two cracks examined from the $\mathrm{G}-8$ sample, where the maximum penetration was somewhat greater $(\approx 6 \mathrm{~mm})$. 
The rent nature of the 308L stainless steel within the crack of $\mathrm{E}-6$, which was also typical of the G-8 crack, is evidence of the elevated-temperature ductility of the Type 308L weldment and the hot tearing along interdendritic boundartes that resulted in the cracks. The hot tearing would have been caused by the thermal stresses when this hot-spot area cooled rapldly at $\approx 10-100^{\circ} \mathrm{C}$ per min.

The SEM examination of the materials found in the E-6 and G-8 cracks revealed evidence of molten material that was present at, or shortly after, formation of the cracks. The principal constituents of this material, which appeared to be layered on the exposed crack surfaces, were $\mathrm{Fe}, \mathrm{Cr}$, and $\mathrm{NI}$, together with $\mathrm{Sn}$, In, Ag, and $\mathrm{Cd}$ in combinations as second phases or discrete metallic particles within the general oxidized matrix. The appearance of the material Indicated that it was not a surface oxidation product, but had once been molten and was Interacting with the cladding in a solld/liquid reaction. These elements are the essential constituents of the Zircaloy-shrouded, stainless-steel-clad Ag-In-Cd control rods. The extensive gray structure in the root of the crack, however, was principally the Fe oxidation product of A533 vessel steel laced with a solidined Sn-In phase. Fuel particles were found only on top of the oxidized layers or as minor constituents of the layers. The absence of signiflcant quantities of fuel in the cracks indicates that the massive fuel flow to the lower head was not the source of the solidilled material in the cracks.

Inclusions of $\mathrm{Ag}-\mathrm{Cd}$ were found in numerous intergranular tears on the surface and well Into the cladding $(=4 \mathrm{~mm})$, as shown in Fig. 10 . It is quite likely that interdendritic penetration of these materials as liquids contributed to the hot tearing of the cladding. Copper was also found in the cladding, next to the cracks, suggesting another causative agent for the hot tearing.

These observations on the superposition of core materials in the cladding and in cladding cracks suggest that the control-assembly materials were already on the lower head when the massive fuel now from the core region arrived. Because the control-assembly materials would have reached the lower head as solids, they apparently were remelted by the fuel flow. resulting in intergranular penetration of the cladding by $\mathrm{Ag}-\mathrm{Cd}$.

\section{Examination of Instrument Tube Nozzles}

Background Information. Fourteen instrument-tube-nozzle segments were removed from the lower head of the TMI-2 reactor for detalled examinations as part of the Vessel Integrity Project (VIP). Six of these were examined at Argonne National Laboratory-Illinols (ANL) and elght were to be examined at the Idaho Natlonal Engineering Laboratory (INEL). The objectives of the nozzle examinations at ANL were to (1) provide information on the temporal and locational movement of fuel onto and across the lower head: (2) estimate peak temperatures of the nozzles from their metallurgical end-state: and (3) determine the mechanisms, modes, and extent of nozzle degradation to evaluate the possible damage to the lower head. Corollary objectives to focus the examinations were to (1) determine the nature and extent (axial and radial) of fuel/debris ingress into a nozile: (2) determine the nature and degree of chemical and thermal interaction between fuel, debris, and noz:ies; (3) determine thermal-related metallurglcal changes in the nozales as a function of axial position to evaluate the axial temperature distribution and attempt to quantify temperatures near the vessel: and (4) determine the position and composition of debris adhering to nozile surfaces to eslablish a "debris bed depth." Because of problems with the hot-cell, the examinations at INEI, were 


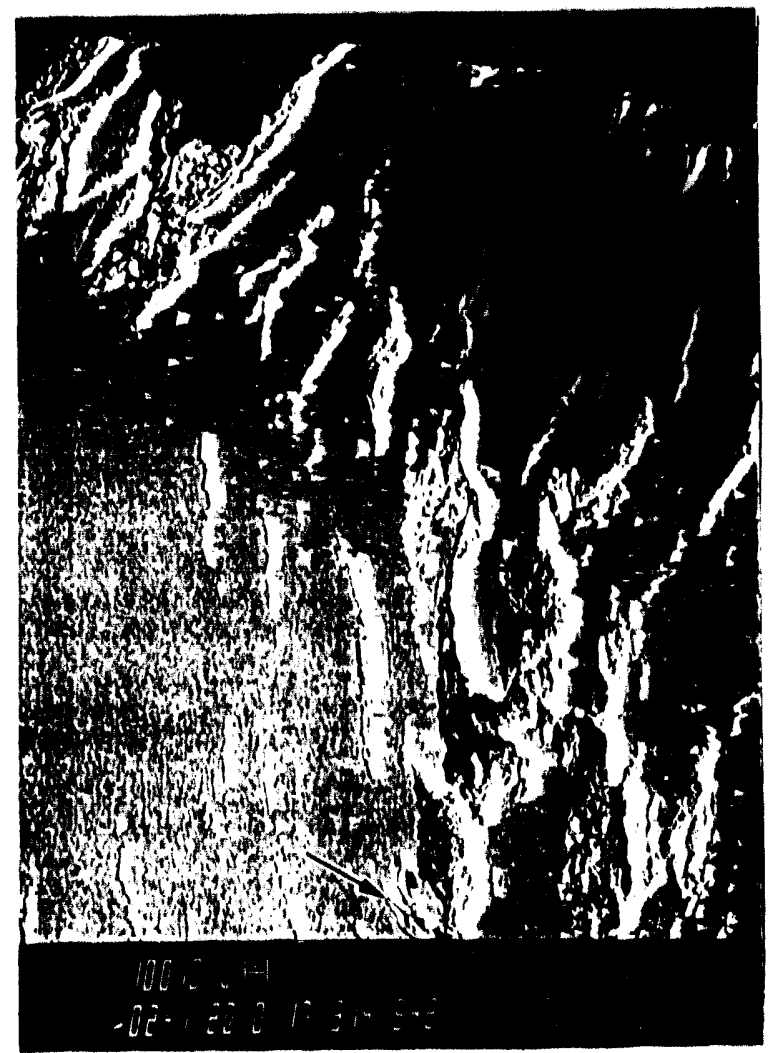

Fyg. 10. Inclusions of $\mathrm{Ag}-\mathrm{Cd}$ in intergramular tears in cladding of Sample G-8.

not as complete as planned. Therefore, the results presented in this paper will be princlpally from the ANL examinations.

The nozzle segments recelved at ANL were from locations D-10, E-11, H-5, H-8, L-6, and M-9 (Fig. 1). These nozzles exhiblted the range of damage suffered by all the nozzles, l.e.. from melt-off at a low elevation to none, and, based on their core location and degrees of damage, were representative of those at INEL, also.

The detalled results of these nozzle examinations are reported in Ref. 13. Only the most signiflcant indings are summarized in this paper.

Examination Methods. The examination methods used at ANL consisted of visual examination and macrophotography, axial gamma scanning for $137 \mathrm{Cs}$, macroexamination of cut surlaces, metallography, microhardness measurements, and scanning electron mtcroscopy/energy-dispersive X-ray (SEM-EDX) analysis.

The nozjle segments were systematlcally sampled for detalled examination to obtain the desired data. Sectioned areas were based on the following attributes: (1) top and bottom locations, to obtain information on the hottest (sometimes molten) and coldest (nearest the vessel) temperature extremes in a nozyle: (2) fiuel/nozzle interaction areas (nozile degradation 


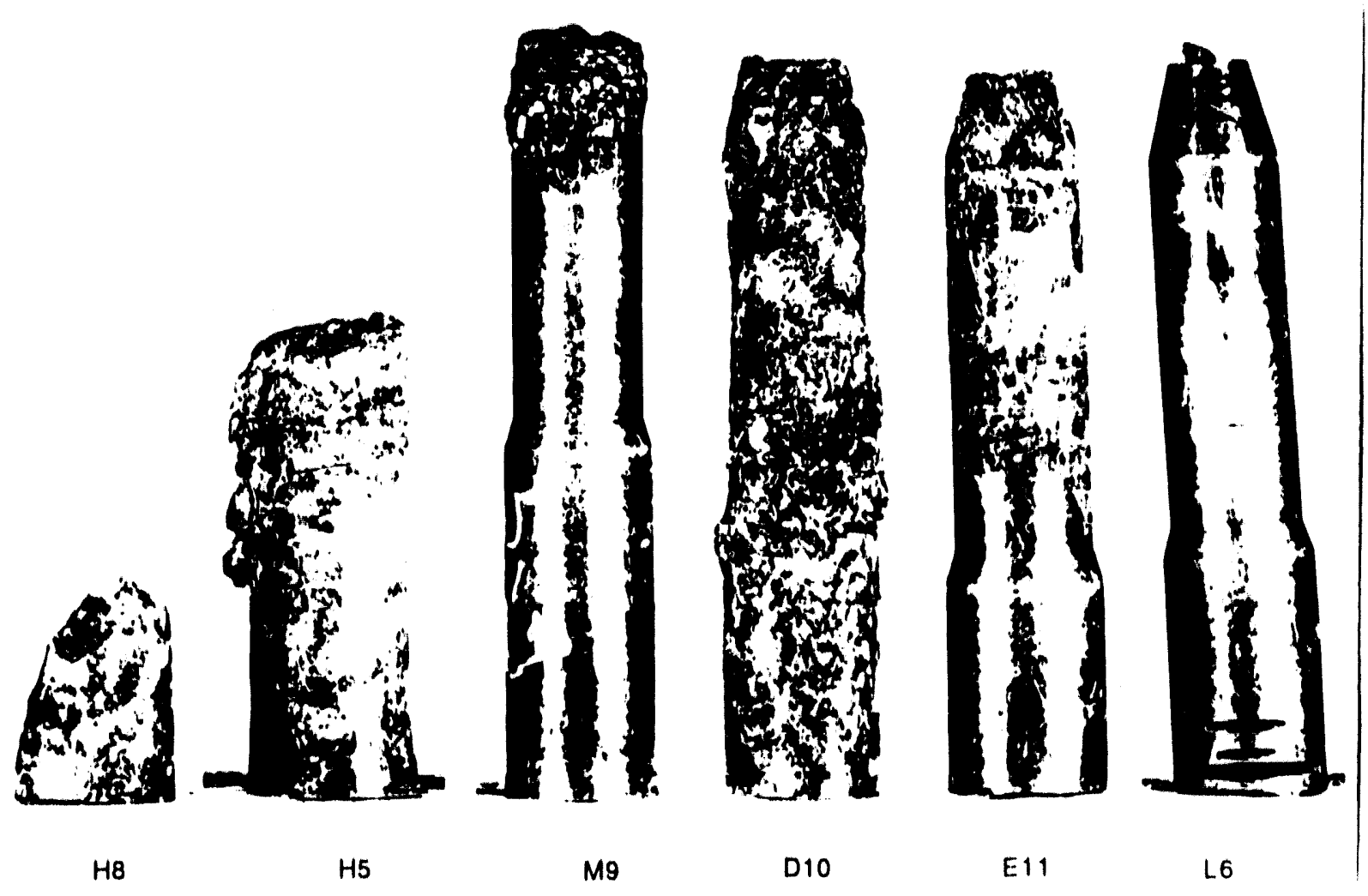

Fig. 11. Appearance of nozzles as removed from the lower head.

mechanism); (3) Indications from gamma scans of fuel penetration Into the nozzle; (4) obvious locations of debris on a nozzle: and (5) locations of surface cracking (nozzle degradation mechanism).

Pattern of Nozzle Damage. Figure 11 shows the as-removed appearance of the six ANL nozzles: Table 1 should be used to obtain a true comparison of the elevations at which nozzle damage occurred because the stub lengths remaining on the vessel were different for each nozzle. The tops of nozzles $\mathrm{M}-9$ and $\mathrm{H}-5$ were clearly melted an appreclable amount. The transition zone between the molten region and the unaffected lower part of the nozzles was relatively narrow on M-9 and more extenslve on the shorter H-5. These transition zones were typically covered with a thin scale that was basically an iron oxide with entrapped shards of various core debris materials (Fig. 12); the lower areas of the nozzles were clean of adherent scale and showed little, if any, elfects of being in contact with very hot core debris.

Significant fuel penetration into these molten nozales was essentlally limited to the melted and scaled elevations. 1.e., the hot top of the nozzle. The materlal found in the top of nozzle M-9 (Fig. 13) was a mixture of solidined fuel and nozele remnants in a matrix of chromlum oxide from the Inconel 600 norzle material; this oxide was different from the $\mathrm{Fe}$ based oxide scale on the outside of the nozzles. It is believed that the ability of the fuel to penetrate downward into the nozzle was limited by the $\mathrm{Cr}$ oxide in which it was trapped ( $\mathrm{Cr}_{2} \mathrm{O}_{3}$ melts at $\left.1990^{\circ} \mathrm{C}\right)$. 
Table 1. ANL Nozzle Segment Lengths, Elevations, and Fuel Penetration Depths (in $\mathrm{mm}$ )

\begin{tabular}{|c|c|c|c|c|c|c|}
\hline Nozzle & $\begin{array}{l}\text { Elevation } \\
\text { of Nozzle } \\
\text { Base }\end{array}$ & $\begin{array}{l}\text { Segment } \\
\text { Length }\end{array}$ & $\begin{array}{c}\text { Stub } \\
\text { Length }\end{array}$ & $\begin{array}{l}\text { Elevation } \\
\text { of Top of } \\
\text { Segment }\end{array}$ & $\begin{array}{c}\text { Fuel Penetration } \\
\text { Elevatlon above } \\
\text { Nozzle Baser }\end{array}$ & Condition \\
\hline M-9 & 119 & 254 & $26^{d}$ & 280 & 241 & $\begin{array}{l}\text { Melted ofr; some } \\
\text { scale }\end{array}$ \\
\hline L. 6 & 94 & 241 & $634^{d}$ & 305 & 75 & Intact, shiny \\
\hline$H \cdot 5$ & 107 & 146 & 0 & 146 & $\begin{array}{l}89 \max \\
117 \mathrm{~min}\end{array}$ & Melted ofr: scale \\
\hline $\mathrm{H}-8$ & 0 & 70 & 51 & 121 & $<64$ & $\begin{array}{l}\text { Melted ofr: liquid } \\
\text { ablation in center }\end{array}$ \\
\hline D- 10 & 244 & 235 & $57^{d}$ & 292 & $\begin{array}{l}55 \max \\
184 \mathrm{~min}\end{array}$ & $\begin{array}{l}\text { Crusted and } \\
\text { softened one slde }\end{array}$ \\
\hline E-11 & 221 & 225 & $77^{d}$ & 302 & 204 & TIp melted; scale \\
\hline
\end{tabular}

Referenced to vessel low point at $\mathrm{H}-8$.

bReferenced to nozzle base.

cBased only on gamma scans.

dCalculations as the difference between $305 \mathrm{~mm}$ and the sum of the two known values. Measurements of stub lengths for D-10 and E-11 from photographs were not deemed sumciently accurate because of angle of photo.

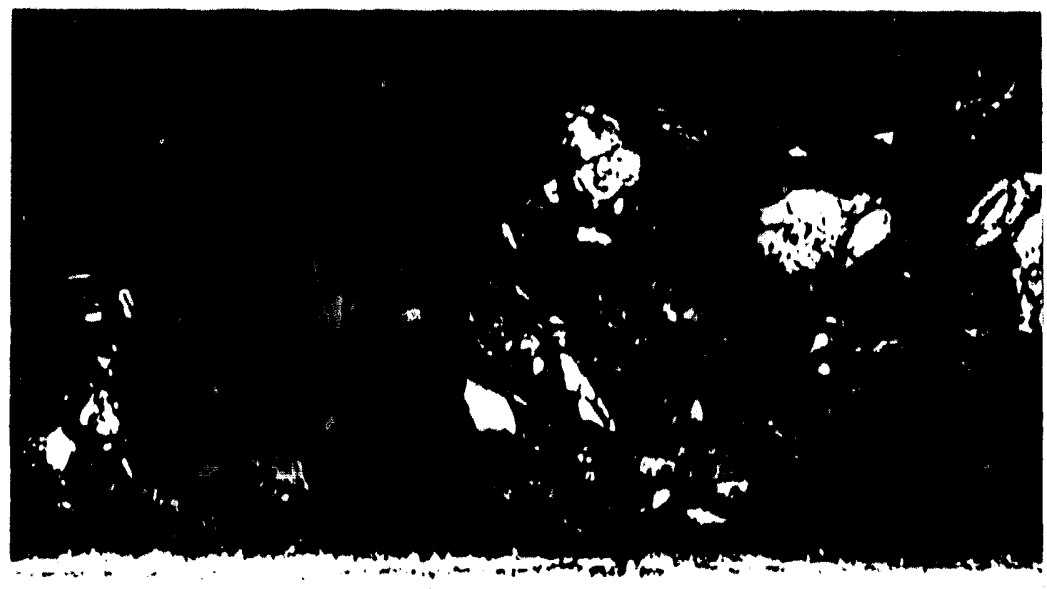

Fig. 12. Layer of Debrts on Outer Surface of D-10 at the 82-mm Elevalton. (190X, 281852) 


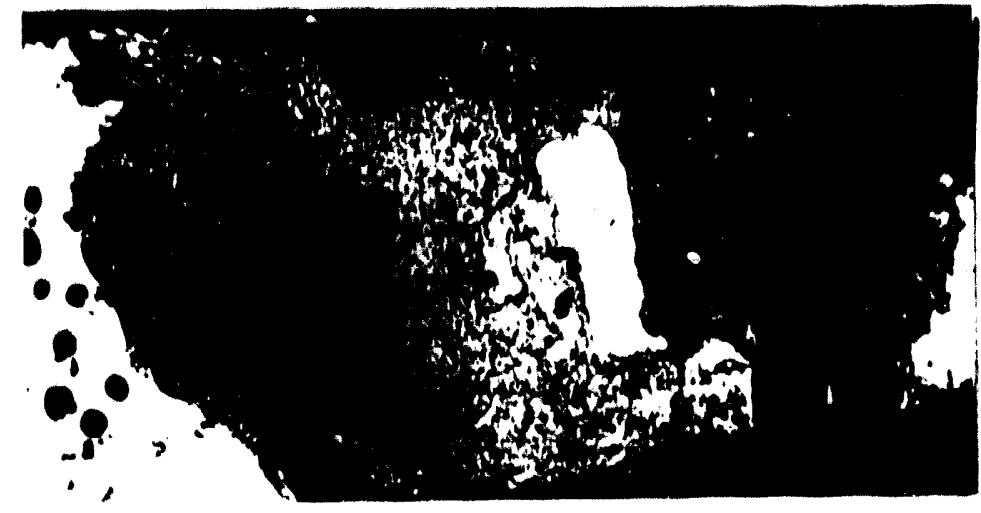

Fy. 13. Longitudinal Section through Top of Nozzle M-9 (7X).

The H-8 nor:ile segment recelved at ANL was only the bottom portion of a longer postaccident segment, the top of which was broken ofl during the removal operations. The top surface of the bottom portion, shown in Fig. 11, was smooth compared to the melted reglons of M-9 and H-5. Upon detalled examination by SEM-EDX, It was found that this surface had reacted extensively with a molten $\mathrm{Zr}$-rich phase that contained ingots of Ap-Cd. These elements would have come from control assembly components that apparently melted early in the accldent and deposlted on the lower head in advance of the major fuel flow there. Intergranular penetration of $\mathrm{Ag}-\mathrm{Cd}$ was lound in a number of nozzles and into the surface of the vessel cladding. ${ }^{3}$

In contrast to the melted condlition of nozzles M-9 and H-5, nozzle L-6 (almost midway between them on the lower head) showed no external damage at all. This indicates that the luel movement in the lower head was not one unilled now, but rather individual nows from ditierent ditrections.

Although the surface of nozgle 1.-6 was clean, the nozje contained solidilled luel masses down to within $75 \mathrm{~mm}$ of its base, the decpest penetration in any noz:le. This deep p netration is attributed to the lack of fuel/nozjle Interaction that would have formed a binding $\mathrm{Cr}$ oxide. Because both the nozzle and $\mathrm{Its}$ overlapping gulde tube were undamaged. the source of this fisel is not obvious: it would have been dimcult for molten fuel to have come up under the guide tube and down into the nozzle without damaging elther unless the liuel was not very hot but still moblle. It could be concluded that the fuel came down directly through the gulde lube from somewhere up in the reactor.

Nozale D-10 was at the periphery of the lower head and appears to have been on the edge of the llow of mollen fiuel. One slde of the nozile was heavlly crusted along its entire hetght. whlle the other side, in a $180^{\circ}$ arc, showed only the more common light surface scale. Upon sectioning, It was found that an unexplatned internal pressurtzation had pushed out the hot. crusted side of the nozzle, making II egg-shaped in cross section. The internal pressure created a crack in the outer surface of the noz:le and also collapsed the Inner Inconel 600 tube of the instrument string. The body of the nozzle had undergone intergranular hot tearing, which apparently penetrated to the surlace and lormed the crack. The nonuntform damage indicates that these events occurred quickly. with no tlme for heat transfer to the 
rest of the nozzle. This could be expected at the edge of a fuel now coming to rest agalnst the nozile.

The last nozzle, E-11, was damaged only at its tup, below which was a fairly extensive area of the Fe-based scale. Melting was limited to the inner and outer surfaces of the tip, with Indications of rapid melting and solidification. Fuel penetration was relatively deep (compared to that in M-9) apparently because the temperature at the top was too low to form $\mathrm{Cr}$ oxide that llkely would have limlted downward fuel movement. Instead, the material in the tip of the nozzle was in an Fe-based oxide, similar to that of the surface scales.

Two principal points may be concluded from the variable degradation of the Instrument tube nozzles. First, considering that most of the nozzles on the lower head were covered with a hard, solidined layer of fuel debris, but that nozzles such as L-6 sustained no outward damage from contacting this debris, it can be concluded much of this debris acted as an insulator and protector of both the norzeles and the lower head. The absence of virtually any indication of degradation in the bottom parts of nozzles (even in those whose tops had melted) Indicates that what was likely the first fuel debris to reach the lower head solldified relatively quickly and bullt up a signincantly thick Insulating layer. Once this layer had bullt up. the later material arriving on top of the solidifled material melted off the tops of those nozzles that were exposed. The elevations at which these melt-olls occurred provide evidence for the thickness of the Initlal protective layer at varlous locations around the lower head. Thus, the fact that the nozzles in the vessel hot-spot area of E-F/7-9 were melted down the most indi. cates that only an initually thin insulating layer existed there, which apparently was the reason the hot spot formed where it did.

The second point that may be concluded is that the fuel debris movement across the lower head was not one masslve, unidirectlonal now, but more likely a number of llows from different directions. This derives from the lower head locations where speciflc nozzles melted off and the elevations at whlch they melted. The melt-off of M-9. In the eastern slde of the lower head at a relatively high elevation. Indicates a thick initial layer there with the subsequent hot fuel moving downward toward the reactor center atop this thick crust. Simllarly, noz:eles H-5 and G-5 were melted oft atop a somewhat thinner initial crust, whereas nor:ile L-6 did not melt because it was totally covered initially with relatively cold debris. These crust thicknesses are likely indicative of the amount of molten core material that initlally solidined on these locatlons, and indeed these locatlons correlate with the locations in the elliptical now distributor through which debris is believed to have come. Debris llowing downward atop initlal crusts at M-9 and $\mathrm{H}-5$ would effectlvely be moving toward the area of short, melted-olt nozzles where the vessel hot spot occurred.

Penetration of Materiale Into Nozzles. The penetration of gamma-actlve materials downward into the noziles was estimated from the $137 \mathrm{Cs}$ gamma activity profles; the results are summarked in Table 1. It was assumed that the gamma activity was assoclated with ilssion products in fuel, and therefore the results are reported as "liuel penetration." Metallic debris, essentlally molten Inconel from the nozyle, was also found in the noyses, but not tabulated.

Although porous, ceramic-appearing matertal was seen in the as-cut transverse sections at elevations below the nozjle tops, such as in H-8 and L-6, there seemed to be ditliculty in retaining this material during the subsequent sectioning operations to form metallographic mounts. This attests to the friable nature of the material. In most cases, fuel material that 
was retained at the lower elevations had two leatures. First. It appeared to be in the early stages of transformation to U-rich and $\mathrm{Zr}$-rich phases, Indicating relatively rapld cooling. Second, It contained $\mathrm{Fe}, \mathrm{Al}$, and $\mathrm{Cr}$ in the grain boundartes, Indicating likely nuldity signincantly below $2000^{\circ} \mathrm{C}$. That would ald the fuel's mobility to the elevation where it nnally solidi. ned. 14

In norzles M-9 and H-5, which melted ofr, the penetration was shallow: this indicates a quick melting and relatively rapld cooling. notwithstanding the phase transformations in the fuel areas. It is likely that the melting point of $\mathrm{Cr}$ oxide dominated the mobllity of this material before thermal equllibrium and lower-melting eutectics could form. The phase transformation of the fuel would have occurred below $1990^{\circ} \mathrm{C}$ while the solidined fuel was trapped in the Insulating $\mathrm{Cr}$ oxdde. In contrast, porous fuel was found at the base of the H-8 nozzle segment, far below where the nozzle apparently had melted, 1.e.. In the part of the nozzle not received at $A N L$. This fuel may have entered the breach where the nozale had Interacted with liquid $\mathrm{Zr}$ and at too low a iemperature to form $\mathrm{Cr}$ oxide.

The fuel in the tops of D.10 and E.11 difTered from that in M.9 and H.5 In that It was trapped in an Fe- rather than a $\mathrm{Cr}$-based matrix. This reflects two probabllities. First, the Inconel did not readlly give up its $\mathrm{Cr}$ to uxidation, probably because the temperature was too low. Second. the source of the fuel and the Fe-based matrix was probably the same as that of the Fe-based surface scales. That many of the fuel particles were shards and not solldined insitu masses Indicates that the fuel how in this region of the vessel was cooler than the llow that contacted M-9, H-5, and H-8. This is consistent with a scenarto that has the fuel now coming to the vessel hot spot from the east and south and plling up on the far side against D. 10 and E-11. (Note that the surface crust and major heating load was only on one side of D. 10.1

Presence of Control Assembly Materials. There is pervasive evidence from the ANI. examinations that materials from assemblies containing Aq-In-Cd deposited in some form. probably as solld particulates, on the lower head before the princlpal fuel flow occurred at 226 minutes. Unfortunately, there is no direct, unequivocal evidence that a control rod debris bed existed on the lower head. Most, If not all, of such a control rod debris bed would have remelted and possibly been consumed when It came in contact with even the inllial, cooler fuel that reached the lower head ilrst. Therelore, evidence for such a bed would now be, at beet on a microssople scale and fortultously derived.

The evidence that exists Incudes the following: (1) the linding of Ag-Cd nodules and In. Fe-NI-Zr phases solldilled the vessel cladding crucks of boat samples E-6 and G-8: (2) signillcantly higher than expected $\mathrm{Zr}$ and $\mathrm{Ag}-\mathrm{Cd}$ content on surface of $\mathrm{H}-8$ norsle; (3) Aq and Ag.Cd penetrating intergranularly into the surface of numerous noz:ales, and (4) a layer of 10 . $\mu \mathrm{m}$. Ag-Cd particles on the surface of E-11, beneath the liuel debris scale.

The signilicance of a control material debris bed could be twotold. First, Intergranular penetration of the vessel cladding by $\mathrm{Ag}$-Cd may have played a role in the hot learing of the cladding. And second, control material interaction with the nozje material was at a low elevation that may have allowed greater penetration of molten fiuel into nozgle $\mathrm{H}-\mathrm{8}$ than otherwise would have occurred. A third consideration, a potentlal insulating effect of the debris bed on the thermal Impact to the vessel, could not be supported by a heat transter anal. ysis. 
Test specimens were cut Irom the lower head samples in order to determine the mechanical properties of this material under the accident conditions. The tests conducted Included tenslle tests at room temperature and $600-1200^{\circ} \mathrm{C}$. stress-rupture tests at 600 $1200^{\circ} \mathrm{C}$, and impact tests over the temperature range from -20 to $+300^{\circ} \mathrm{C}$. The room temperature tenslle tests were conducted for the purpose obtaining comparisons with Ilterature data: the minimum temperature of $800^{\circ} \mathrm{C}$ for the remaining tests reflects the judgment that little or no damage would have occurred to those portions of the lower head for which the maximum temperature did not exceed this value and that fallure was unlikely at these locations. The maximum temperature of $1200^{\circ} \mathrm{C}$ for these tests lles slightly above the maximum lower head temperature belleved to have been attained during the accident.

The tests were conducted on specimens with varlous prior thermal historles resulung from the accident. Because the number of specimens from the highest-temperature portion of the lower head was limited, It was necessary, in some cases, to heat treat low-damage specimens before testing to produce the corresponding microstructure. This heat treatment consisted of heating the specimen to $1000^{\circ} \mathrm{C}$, holding it at this tempcrature for $2 \mathrm{~h}$. and then cooling it to room temperature at $-10-50^{\circ} \mathrm{C}$ per min. For specimens to be tested at $1000^{\circ} \mathrm{C}$ or greater, this prior heat treatment was omitted, because its effects would be negated by the thermal treatment imposed during testing.

Tenulle Teate. The tenslle tests were conducted in general accordance with ASTM Standards E8 and E8M, using a rectangular-cross-section specimen that also complied with applicable standards of the Deutsches Institut für Normung (DIN). All elevated-temperature tests were conducted in an Ar or He environment. The strain rate for the elastic portion of the loading was $55 \times 10^{4} \mathrm{~s}^{-1}$, and the strain rate during plastle loading was $4 \times 10^{-4} \mathrm{~s}^{-1} \pm 1 \times$ $10.4 \mathrm{~s} \cdot 1$. The reported yield strength values were obtained by the $0.2 \%$ oltset method, except where discontinuous yielding occurred: in these cases, the observed upper yield strength was reported.

The results of the tenslle tests conducted on the lower head base-metal specimens are presented in Fig. 14. These tests were carried out at ANL as well as in Belglum, France, and Spain. Also plotted in Fig. 14 are average values reported by the Japanese National Research Instltute for Metals (NRIM) lor llve other heats of A533. Grade B steel. ${ }^{15}$ The NRIM data were obtalned at a strain rate of $5 \times 10^{.5} \mathrm{~s} 1$ up 10 yleld and $1.25 \times 10^{.3} \mathrm{~s}^{-1}$ for the remainder of the lest. The NRIM tenslle strength data suggest a straln-aging eflect between 100 and $300^{\circ} \mathrm{C}$. resulting in a local tenslle strength minimum at $=150^{\circ} \mathrm{C}$. Both the tenslle and yield strengths of this alloy are strongly temperature dependent: the room-temperature values are reduced by more than a factor of 2 at $600^{\circ} \mathrm{C}$ and by more than a factor of 10 at $900^{\circ} \mathrm{C}$.

The data for specimens taken from lower head samples E.6 and E-8 are plotled separately in Fig. 14, and these data lie significantly above the best-flt curve to the remaining data. It has been determined that both of these samples were heated to maximum temiperatures of $=1000-1100^{\circ} \mathrm{C}$ during the accident, followed by a relatively rapldly cooling. ${ }^{2}$ The resulting hardening has produced slgnifleant increases in strengih at both room temperature and $600^{\circ} \mathrm{C}$.

Stress-Rupture Teats. The stress-rupture lests used the same specimen design as the tenslle lests, and lesting was carrled out in general accordance with ASTM Standard E1339. 


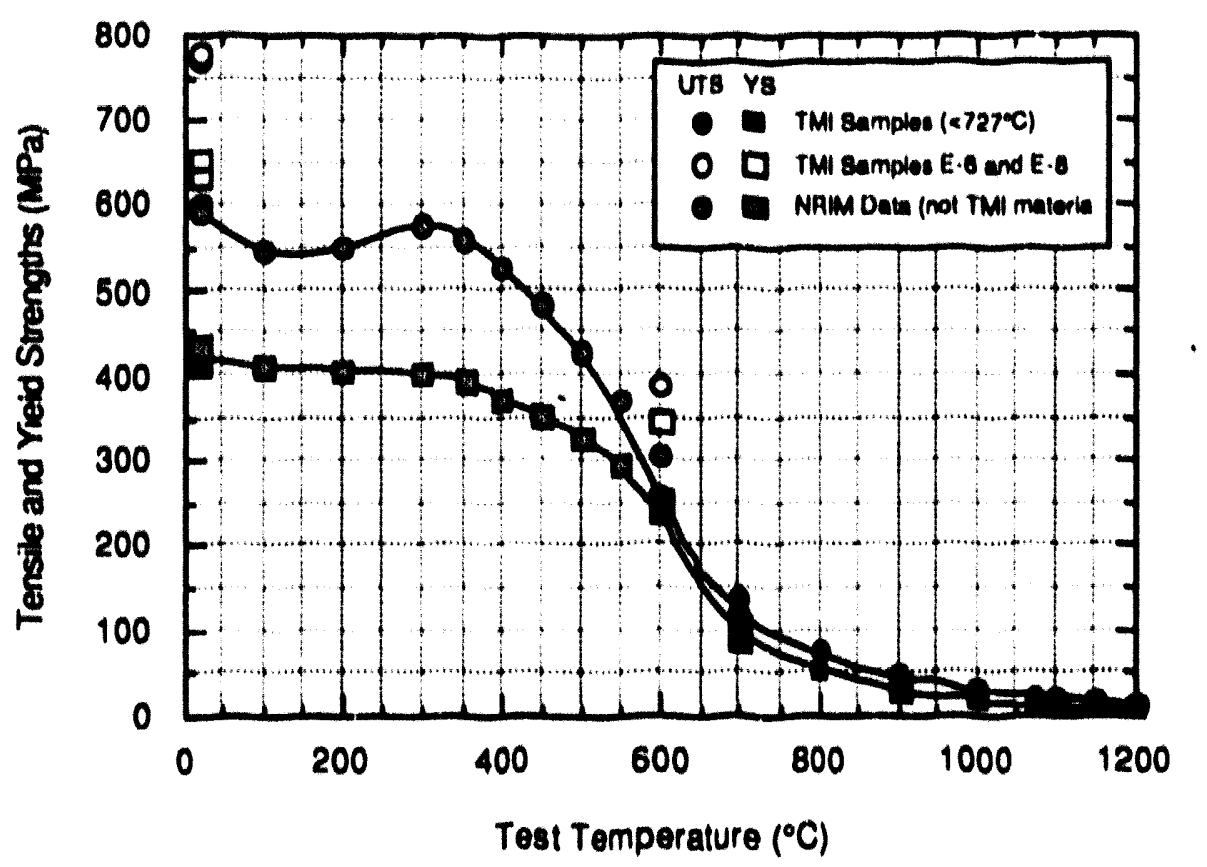

FYg. 14. Tensule and yleld strengths of TMI-2 lower head matertal

These tests were carried out at ANL and in Belgium. France, and Spaln, and the resulting stress-vs.-tIme-to-fallure data are plotted in Fig. 15. The tests were conducted in an $\mathrm{Ar}$ or He environment except those conducted by the SCK/CEN In Belglum. All but one of the Belglan tests was conducted in vacuum: a single test at $800^{\circ} \mathrm{C}$ and $30 \mathrm{MPa}$ was conducted in an $\mathrm{Ar}$ environment.

Matertals with slightly different thermal histortes were tested at both 600 and $700^{\circ} \mathrm{C}$. At $600^{\circ} \mathrm{C}$, tests were conducted on specimens from Sample K.13, for which the maximum temperature during the accident did not exceed $727^{\circ} \mathrm{C}$, as well as on specimens from Sample F.5, for whlch the maximum temperature was apparently somewhat $>727^{\circ} \mathrm{C}$ over a portion of the sample. No significant difference in time to fallure is observed in Fig. 15. This lack of an elfect may be attributed to the fact that the maximum temperature probably did not signiflcantly exceed the transformation temperature of $727^{\circ} \mathrm{C}$ in F.5. particularly in the bottom half of the sample from which the creep test specimens were taken. Similarly at $700^{\circ} \mathrm{C}$, specimens from Sample M-11, for which the maximum temperature may have appronched or sllghtly exceeded $727^{\circ} \mathrm{C}$, show no difference in behavior when compared with specimens from Sample H-8, lor which the maximum temperature remained below $727^{\circ} \mathrm{C}$.

Two time-temperature correlations were explored in an attempt to fit the base-metal creep data. The first of these was the Larsun-Miller parameter $L^{18}$

$$
\left.L=T Y C+\log _{10}\left(t_{1}\right)\right) .
$$

where $T$ is tempcrature in Kelvin, $t_{f}$ is time to fallure in hours, and $C$ is a ittung constant. A least squares analysts determined that the opt Imum value of $\mathrm{C}$ for the present data base was 12.5, and stress $\mathrm{s}$ was related to the IArson-Miller parameter by the relation 


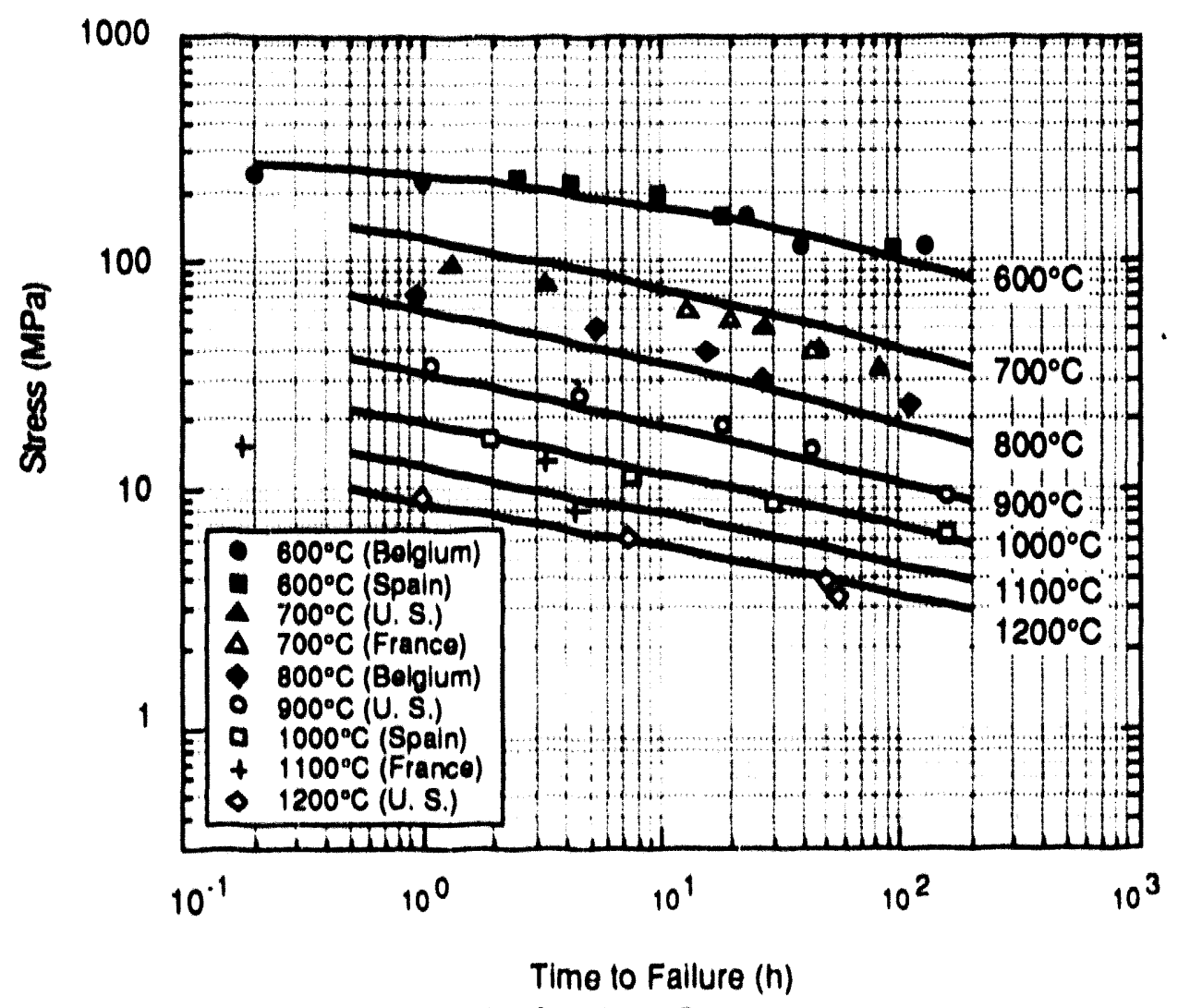

Mig. 15. Stress riplure data with Manson-Haferd best flt

$$
\log _{10}(s)=4.3406 \cdot 0.00018767 \cdot L_{1}
$$

where the applied stress $s$ is in MPa.

The abllity of the Manson-Haferd lime-temperature correlation 17 to the data was also evaluated. The Manson-Haferd parameter $M$ has the form

$$
M=\underset{T \cdot T^{11}}{\log 10\left(t_{1}\right) \cdot t_{n}}
$$

where $t \mathrm{f}$ is tlme to fallure in $\mathrm{h}, \mathrm{T}$ is test temperature in Kelvin, and $\mathrm{t}_{\mathrm{a}}$ and $\mathrm{T}_{\mathrm{a}}$ are ntting constants. A least squares analysis was again carried out, and the optimum values for $t_{n}$ and $T_{n}$ were found to be 7.57 and 520 respectively. Log(s) was found to vary with the Manson-Haferd parameter $M$ according to the relationship

$$
\log _{10}(s)=-0.80 .467 \cdot 261.41 \cdot M \cdot 5291.25 \cdot M^{2} .
$$

A comparison of the resulting best int curves with the actual s vs. tf data in Fig. 15 shows a reasonably good int to the data. However, systematle departures from the actual data are noted In the $700.900^{\circ} \mathrm{C}$ region. This problem may be assoclated, in part, with the ferrite-toaustenlte phase transformation that occurs over the temperature regime from 727 to $\approx 850^{\circ} \mathrm{C}$. 


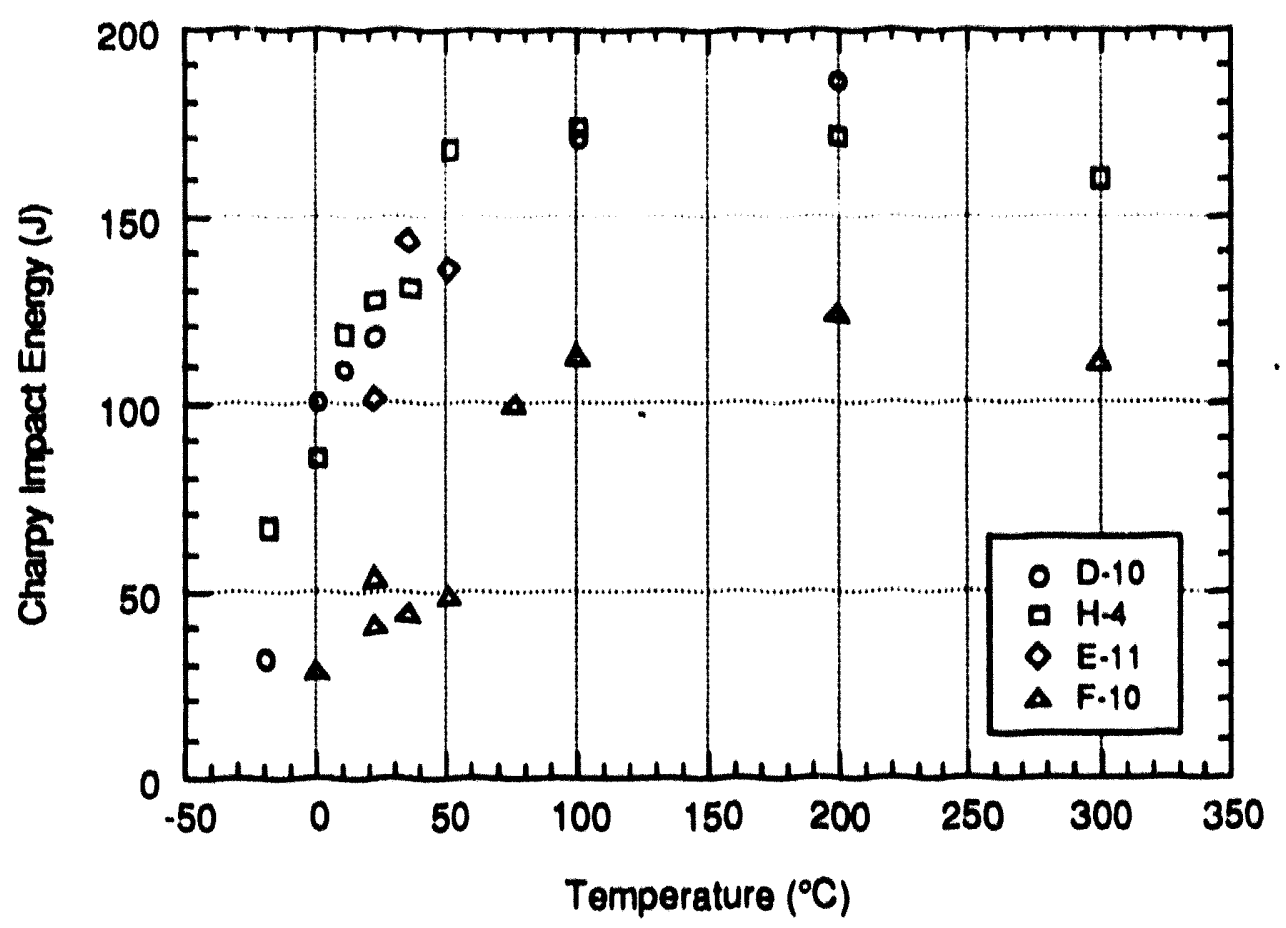

Fy. 16. Absorbed impact energy us. test temperature

Impact Tests. The Impact tests on the lower-head material were conducted in Italys using the procedure and conventional Charpy V-notch test specimen described in ASTM E23. and the data are summarbed in Fig. 16. The three groups of test specimens for which the maxdmum temperature did not exceed $727^{\circ} \mathrm{C}$ show simllar behavior, with an upper shelf energy of $=170 \mathrm{~J}$ and a transition temperature of the order of $20^{\circ} \mathrm{C}$. However, the data from specimens of Sample F-10, for which the maximum temperature was as high as $-1050^{\circ} \mathrm{C}$. stand in marked contrast. The F-10 material shows a significantly higher ductlle-to-brittle transition temperature of $-70^{\circ} \mathrm{C}$, as well as a lower upper-shelf energy of $=120 \mathrm{~J}$. These differences reflect the reduced ductillty and impact resistance that is produced in this material by the high temperatures and relatively rapld cooling assoclated with the accident.

\section{Summary and Conclusions}

Microstructural characterizations and mechanical properties tests have been conducted by INEL, ANL and the OECD partner laboratories on material from 15 locations in the lower head of the pressure vessel of the TMI-2 nucluar reactor. Instrument nozales and gulde tubes from the lower head were also examined. The microstructural characterizations were conducted by conventional optical metallography, hardness measurements, scanning electron microscopy (SEM) on etched specimens and surface replicas, and analytical transmission electron microscopy on thin folls and carbon extraction replicas. The mechanical tests consisted of tensile tests at room temperature, tenslle and creep tests at $600-1200^{\circ} \mathrm{C}$, and Charpy impact tests at $-20-300^{\circ} \mathrm{C}$. The specimens tested were taken from locations where the maximum temperature had not exceeded $727^{\circ} \mathrm{C}$ during the accident and from locations where the maximum temperature had been as high as $1100^{\circ} \mathrm{C}$. The results of these investigations lead to the following conclusions: 
1. An elliptical shaped hot spot approximately $1 \times 0.7 \mathrm{~m}$ on the inside surface of the lower pressure vessel head was heated tc temperatures from $\approx 800$ to $1100^{\circ} \mathrm{C}$ for approximately 30 minutes due to the relocated fuel debris.

2. The remainder of the lower head remained below $727^{\circ} \mathrm{C}$, but some areas may have been close to this temperature.

3. The temperature gradient through the thickness of the vessel wall was of the order of 2 to $4^{\circ} \mathrm{C} / \mathrm{mm}$.

4. The thermal excursion of the lower head was "quenched," l.e., cooled at a rate of the order of $10-100^{\circ} \mathrm{C} / \mathrm{minute}$.

5. The results of tensile tests conducted on base-metal specimens for which the maxdmum temperature during the accident $\left(\mathrm{T}_{\max }\right)$ did not exceed $727^{\circ} \mathrm{C}$ agree well with literature data for A533B steel and show a dramatic drop in strength at temperatures above $600^{\circ} \mathrm{C}$.

6. Tensile specimens from samiples for which $\mathrm{T}_{\max }$ exceeded $727^{\circ} \mathrm{C}$ showed significantly higher strengths at room temperature and $600^{\circ} \mathrm{C}$ when compared to specimens for which the temperature did not exceed $727^{\circ} \mathrm{C}$.

7. Creep tests at 600 and $700^{\circ} \mathrm{C}$ indicated no significant difference in behavior between base-metal specimens for which $T_{\max }$ was of the order of $727^{\circ} \mathrm{C}$ and those for which it was well below this value.

8. The stress-rupture data obtained from base-metal specimens could be more accurately it with a Manson-Haferd time-temperature parameter than a Larson-Miller parameter.

9. Charpy V-notch Impact tests conducted on lower head base-metal material noted a substantial difference between specimens from Sample F-10. for which $T_{\max }$ was as high as $\approx 1050^{\circ} \mathrm{C}$, as compared with specimens from samples for which $\mathrm{T}_{\max }$ was $<727^{\circ} \mathrm{C}$. The $\mathrm{F}-10$ material showed a significantly higher ductlle-to-trittle transition temperature as well as a lower upper-shelf energy value.

10. Cracks through the stainless steel cladding of Samples E-6 and G-8 appear to have been hot tearing phenomena, probably assisted by interdendritic penetration of liquid Ag-Cd.

11. Materials in the cladding cracks suggest the presence of control-assembly debris on the lower head before the massive flow of fuel arrived.

12. The nature of the degradation of nozzles $M-9, H-5$, and $H-8$ indicate that their melt-off was by liquid fuel approaching the nozzles at elevations of $\approx 140$ to $270 \mathrm{~mm}$ above the lower head. Surface scale on the nozzles below the melt-ofls suggests that the liquid was atop a crust of solidified and partially solidined debris that had been cooled below its solidus by contact with the lower head.

13. The flow of very hot material on the lower head followed muluple paths. The damage to nozzles $M-9, H-5$, and $\mathrm{H}-8$ suggests that flows occurred from the east and south, but apparently did not affect nozzle L- 6 because it had already been covered by cooler material that had reached the lower head frst. The pattern of nozzle degradation and the assumed fuel-flow directions are consistent with a vessel hot spot at E-F/7-8 where there was apparently only a thin protective crust.

14. The presence of significant quantities of $\mathrm{Zr}$ an $\mathrm{Ag}-\mathrm{Cd}$ on the vessel to interact with the nozzles is attributed to the prior deposition at that location of control assembly material. 
The depth or nature of such a debris bed could not be confirmed, but the depth is estimated to have been at least $120 \mathrm{~mm}$ at the $\mathrm{H}-8$ location.

15. Fuel debris penetration downward into the nozzles was influenced by the temperature of the fuel at the time of entry; by the composition, and hence the fluidity, of the fuel; by the temperature of the nozzle and its abllity to solidify the debris; and the degree of interaction between the fuel and the molten nozzle in entrapping the fuel in Cr oxdde.

\section{Acknowledgment}

The authors gratefully acknowledge the support and direction provided for this work by C. Z. Serpan, E. Hackett, A. Rubin, and M. Mayfleld of the NRC. The financlal support and significant technical contributions made by the OECD partner laboratories participating in the TMI-2 Vessel Investigation Project Metallurgical Program are also gratefully acknowledged. The following persons at ANL contributed to the completion of this work: T. L. Shearer, D. $O$. Pushis, F. M. Basso, S. L. Phillips, J. A. Zic, W. Kettman, F. Pausche, J. E. Saneckd, A. G. Hins, W. F. Burke, and W. A. Moll. INEL contributors Include G. L. Fletcher and D. V. Miley.

\section{References}

1. J. R. Wolf, J. L. Rempe, L. A. Stickler, D. W. Akers, G. E. Korth, L. A. Nelmark, and D. R. Diercks, OECD-NEA-TMI-2 Vessel Investigation Project Integration Report, Idaho National Engineering Laboratory. TMI V(93) EG10, October 1993.

2. G. E. Korth. Metailographic and Hardness Examinations of TMI-2 Pressure Vessel Samples, TMI V(92) EG01, Idaho National Engineering Laboratory, January 1992.

3. D. R. Diercks and L. A. Neimark, Results of Mechanical Tests and Supplementary Metallographic Examinations of the TMI-2 Lower Head Samples, Argonne National Laboratory. TMI V(93) AL02, June 1993.

4. W. Vandermeulen and W. Hendrix, Examination Report of the Samples of the TMI-2 RPV Recelved by SCK/CEN (Belgium), SCK/CEN, Mol, March 1992.

5. Reljo Pelli, Metallographic Examination of TMI-2 RPV Lower Head Sample E-8 and the Archive Material of Midland Reactor, TMI V(92) SF01, VTT Technical Research Centre of Finland, Espoo, April 1992.

6. F. Le Naour, CEA Contrlbution to the TMI-2 Vessel Material Investigation Project, N.T. SRMA 92-1956, Centre d'Etudes de Saclay, May 1992.

7. H. Ruoff, K.-H. Katerbau, and D. Sturm, Metallographic Examination of TMI-2 Lower Pressure Vessel Head Samples, TMI V(91) D001, Staatliche Materlalprüfungsanstalt. Stuttgart, September 1991.

8. P. P. Milella and F. BIgagll, Charpy V Testing of Specimens of the TMI-2 Vessel Lower Head, TMI V(92) I01, ENEA, Rome, May 1992.

9. L. Pedrero and P. Veron, Metallographic Investigation of TMI-2 Lower Pressure Vessel Head Samples, TMI V(92) E002, Equipos Nucleares S. A., Mallaño, April 1992.

10. A. Ballesteros, TMI-2 Vessel Investigation Project Creep Tests, TMI V(92) E004. TECNATOM, Madrid, February 1992. 
11. E. Lopez Rincón, Testing of Lower Head Specimens in Spain (Tensile Resulls), TMI V(92) E001. CLAT, Madrid, May 1992.

12. J. M. THtchmarsh and R. Cooke, AEA-Technology Examinaitons of TMI-VIP Lower Head Samples, TMI V(91) UK2, AEA Technology. Harwell, September 1991.

13. L. A. Neimark. T. L. Shearer, A. Purohit, and A. G. Hins, TMI-2 Instrument Nozzle Examinations at Argonne National Labonatory. TMIV(93)AL01, Argonne National Laboratory, February 1993.

14. R. V. Strain. L. A. Neimark, and J. E. Saneck1, Nucl. Technol. 87, No. 1 (August 1989), pp. $187-190$.

15. Data Sheets on the Elevated-Temperature Properties of $1.3 \mathrm{Mn}-0.5$ M0-0.5 NI Steel Plates for Bollers and Other Pressure Vessels (SBV 2), NRIM Creep Data Sheet No. 18B. National Research Institute for Metals. Tokyo (1987).

16. F. R. Larson and J. Miller. Trans. ASME, vol. 74, pp. 765-771 (1952).

17. S.S. Manson, "Design Considerations for Long Life at Elevated Temperatures," Proc. Int. Conf. on Creep, London, Oct. 3, 1963, pp. 1-27. 

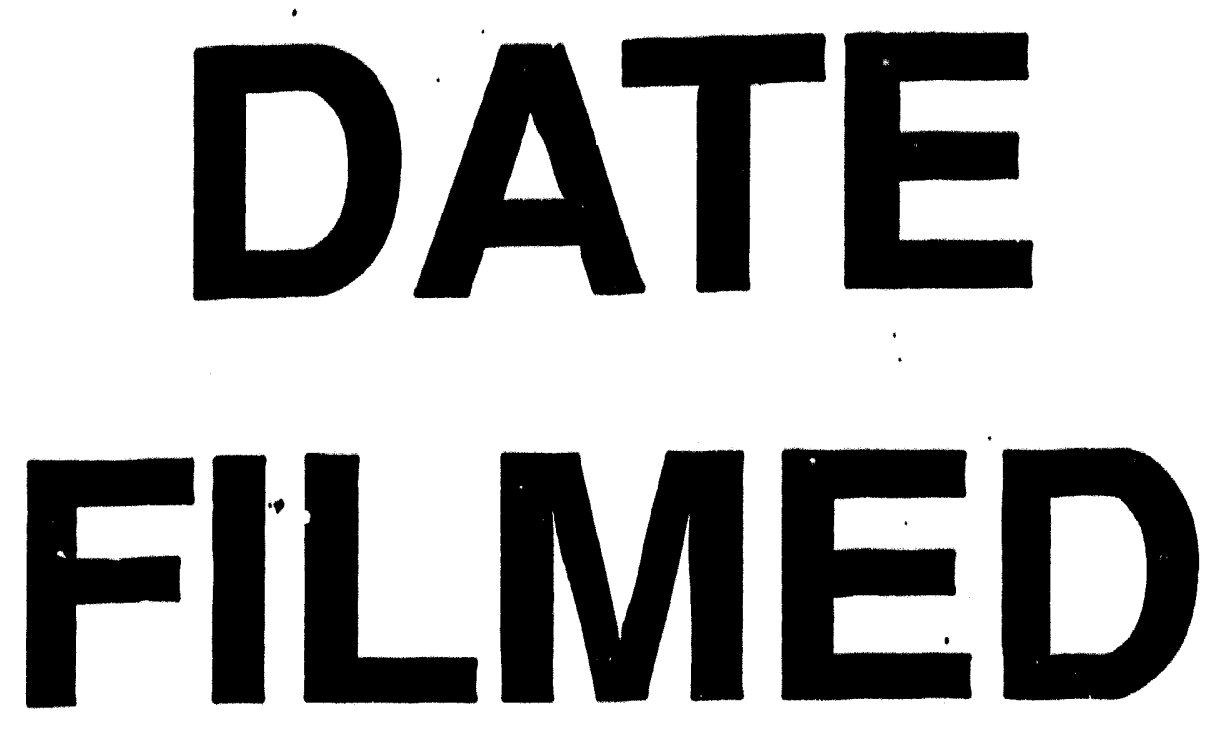

$1 / 6 / 94$
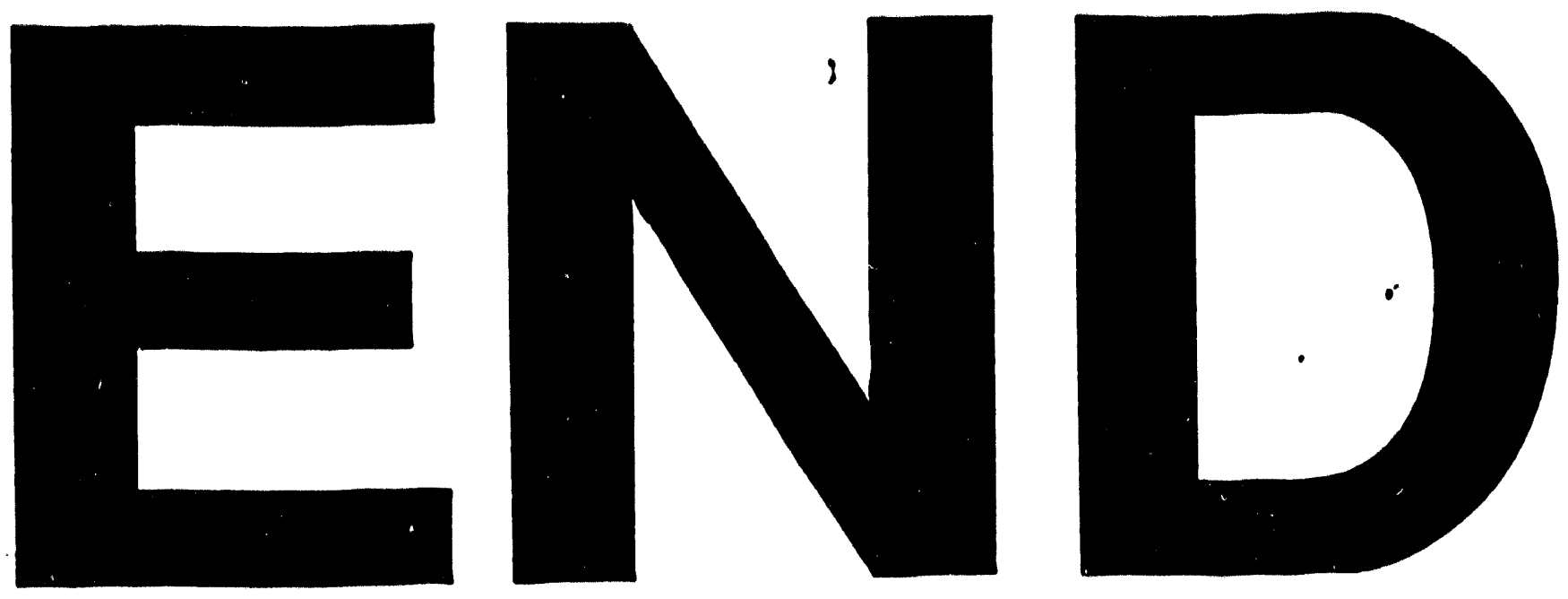
